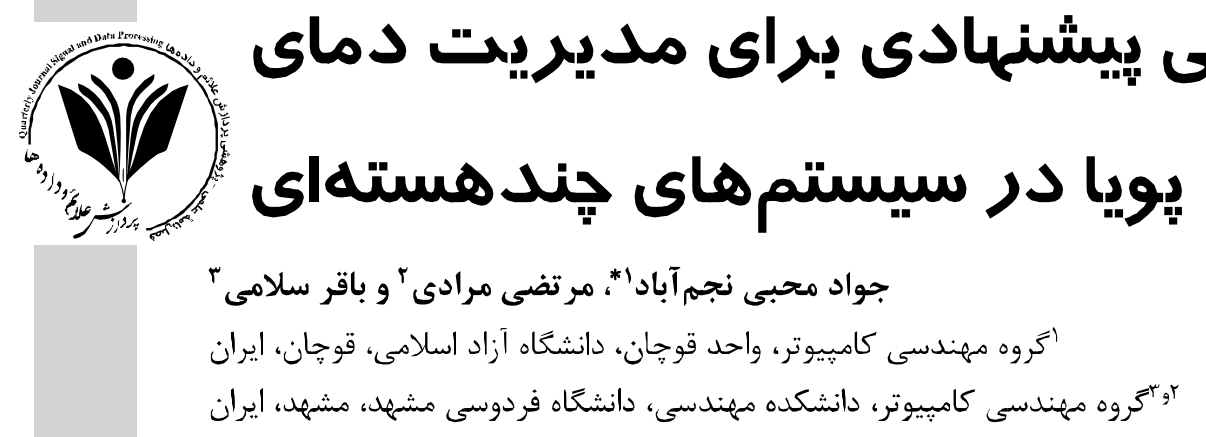

جككيده

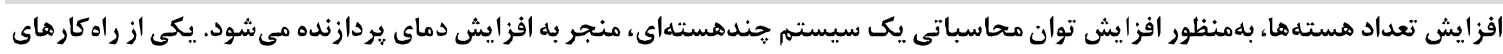

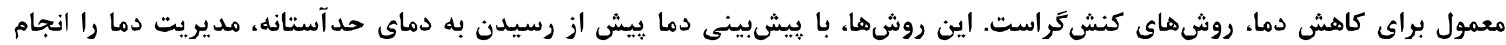

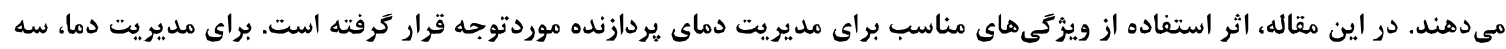

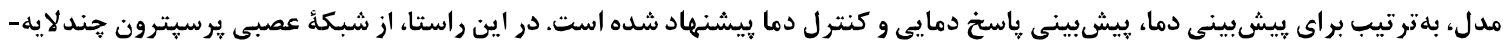

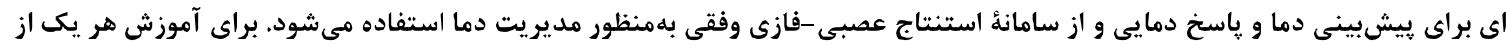

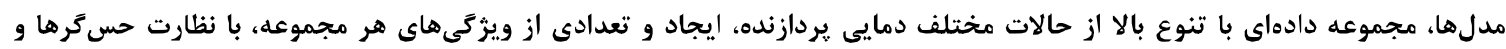

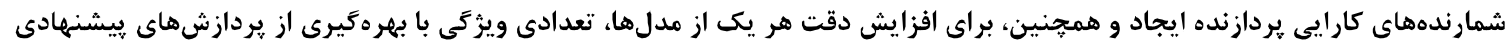

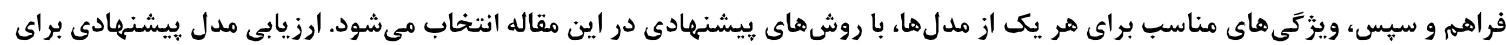

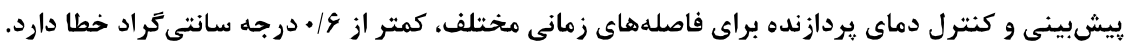

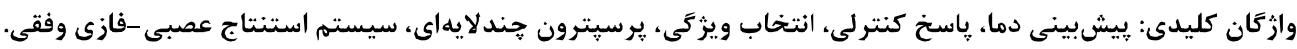

\title{
Proposed Feature Selection for Dynamic Thermal Management in Multicore Systems
}

\author{
Javad Mohebbi Najm Abad ${ }^{1 *}$, Morteza Moradi² \& Bagher Salami ${ }^{3}$
}

${ }^{1}$ Department of Computer Engineering, Quchan Branch, Islamic Azad University, Quchan, Iran

${ }^{2,3}$ Department of Computer Engineering, Engineering Faculty, Ferdowsi University of Mashhad, Mashhad, Iran

\begin{abstract}
Increasing the number of cores in order to the demand of more computing power has led to increasing the processor temperature of a multi-core system. One of the main approaches for reducing temperature is the dynamic thermal management techniques. These methods divided into two classes, reactive and proactive. Proactive methods manage the processor temperature, by forecasting the temperature before reaching the threshold temperature. In this paper, the effects of using proper features for processor thermal management have been considered. In this regard, three models have been proposed for temperature prediction, control response estimation, and thermal management; respectively. A multi-layered perceptron neural network is used to predict the temperature and to control the response. Also, an adaptive neuro-fuzzy inference system is utilized for controlling temperature. An appropriate data set, which includes a variety of processor
\end{abstract}

* Corresponding author * نويسنده عهلهدار مكاتبات 
temperature variations, has been created to train each model. Some features of the dataset are collected by monitoring the thermal sensors and performance counters. In addition, a number of features are created by proposing processes to increase the accuracy of each model. Then, the features of each model are selected by the proposed method. The evaluation of the proposed model for predicting and controlling the processor temperature for different time distances is below $0.6^{\circ} \mathrm{C}$.

Keywords: thermal prediction, control response, feature selection, multilayer perceptron, adaptive neurofuzzy inference system.

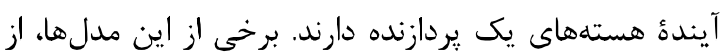

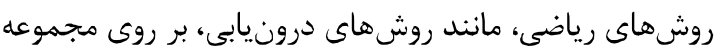

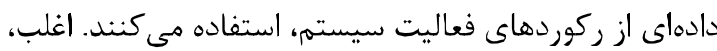

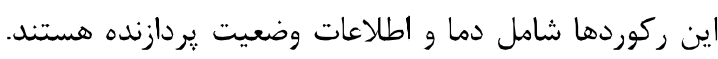
اين اطلاعات در زمان اجراى يك باركارى معمول، با نظارت

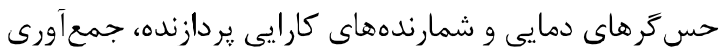

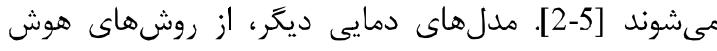

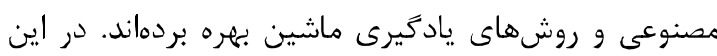

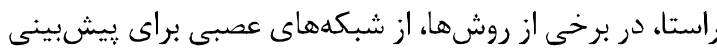

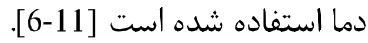
براى اينكه يك مدل دمايى بتواند براى استفاده در يك است الش رويكرد DTM كنش Dرا، مناسب باشد، نياز به داشئ داشتن

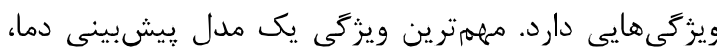

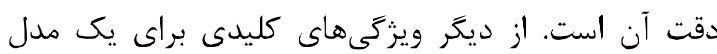

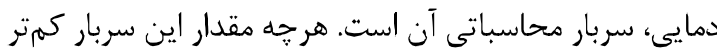

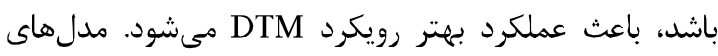
دمايى، در يك رويكرد DTM كنشكرا، رِيشبينى را براى بـاي فاصلههاى زمانى مختلف انجام مى دهند. بازههاى طولانى تر،

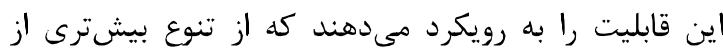
تصميمهاى كنترلى، بر اساس اهداف و محدوديتهائ سيت سيستم

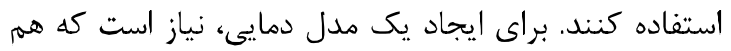

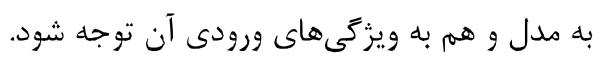

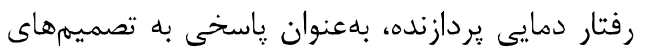

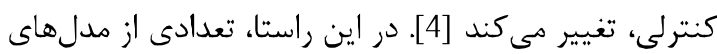

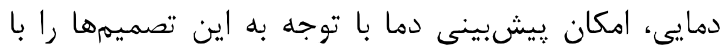

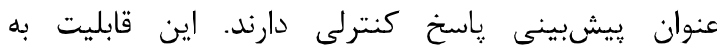

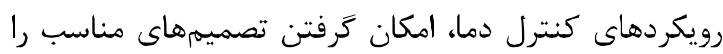

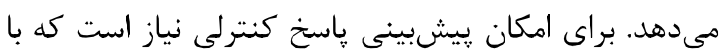

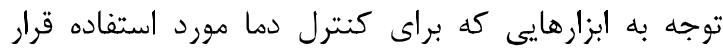
مى گيرند، ويرگى هاى مناسب براى مدل دمايى انتخاب شوند؛

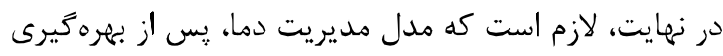

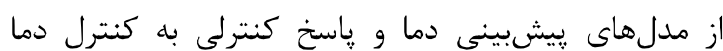

\section{|- 1- مقدمه}

جهت افزايش توان دحاسباتى يردازندهها در ابتدا، از افزايش

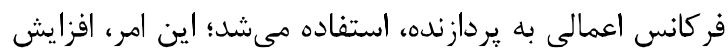

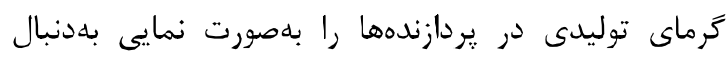

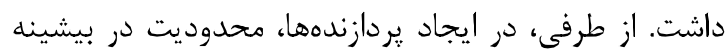

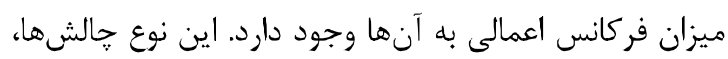

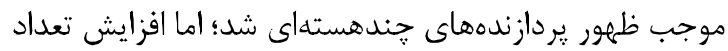

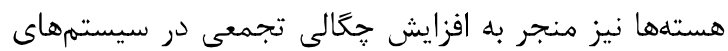
جندهستهاى و بلهتبع آن، افزايش توان مصرفى و درنتيجها

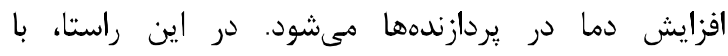

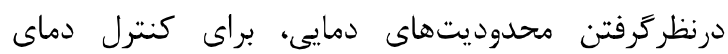

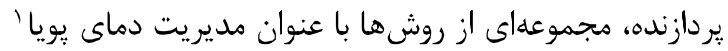

(DTM))، معرفى شدهاند [1].

بلهورت كلى DTM شامل دو رويكرد واكنشى بَ و و

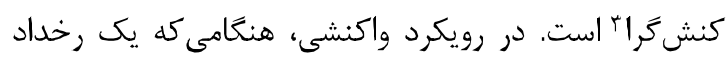

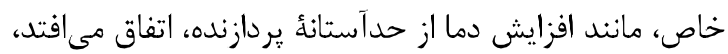

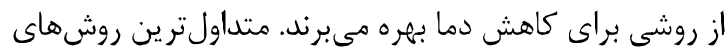
مورداستفاده در DTM، تنظيم ولتاز فركانس يوياء (DVFS) و مهاجرت وظيفه است. در اين رويكرد، ازآنجايى كه، بعد از

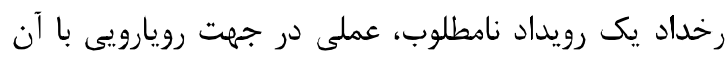

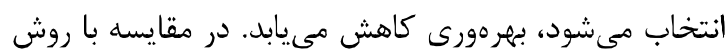

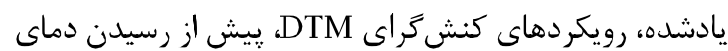

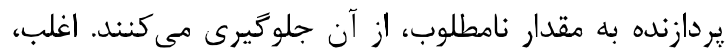

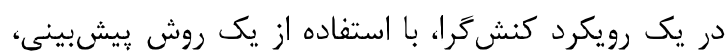

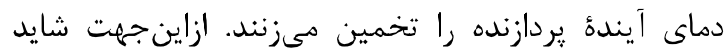

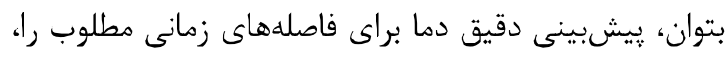

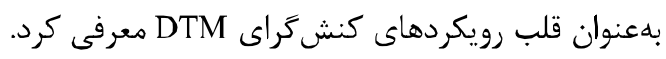
مدلهاى بيشبينى دها، سعى در تخمين دقيق دماى

\footnotetext{
${ }^{1}$ Dynamic Thermal Management

${ }^{2}$ reactive

${ }^{3}$ proactive

${ }^{4}$ Dynamic Voltage and Frequency Scaling
} 
در ادامه، اين مقاله بلصورت زير سازماندهى شده

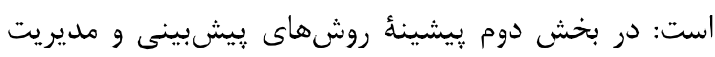
دماى يردازنده مورد بررسى قرار ترفتهاند. تعريفهاى اوليه شامل معرفى سيستههاى جندهستهاى و انتخاب ويزگكى بر هايه اطلاعات متقابل در بخش سوم ارائه شده است. در بخش ونش

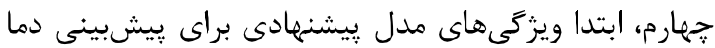
انتخاب مىشوند؛ سيس، به معرفى مدل مناسب براى

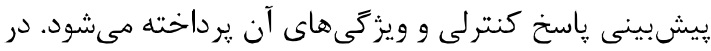

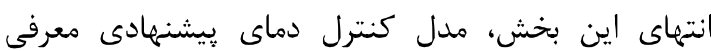
مىشود. نتايج ارزيابى مدلهاى پيشنههادى در بخش ينجم ارائه شده است. در بخش ششم، نتيجهكيرى مقاله بيان مىشود.

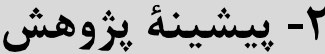

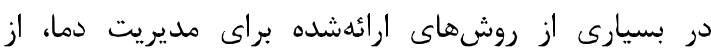
دادهاى آمارى استفاده كردهاند. اين دادهها از اجراى برائ برنامهها

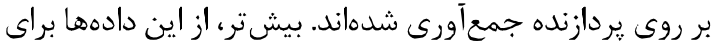
تعيين ضرايب يك معادلأ קندجملهاى دمايى استفاده شده

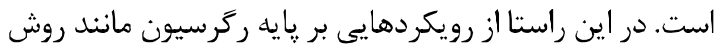
كمينه مربعات بازكَتىى" (RLSM) بهره كرفتنهاند [114] ايجاد مدلهاى مديريت دما مىتواند با بهرهيرى از دادههاى

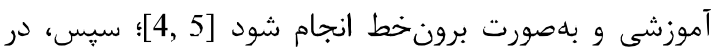

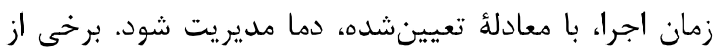

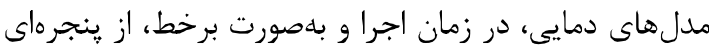
از آخرين مشاهدها براى تعيين ضريبهاى معادله استفاده

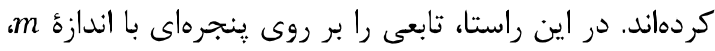

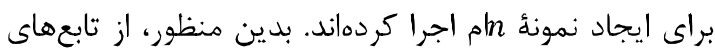
ميانخين ساده، وزندار و نمايى بهره بردهاند [6].

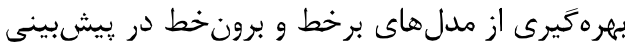

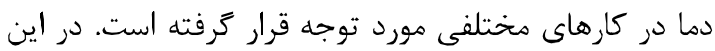

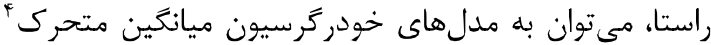
اشاره كرد، كه به هر دو شكل در ويشبينى دما

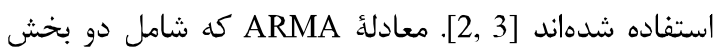

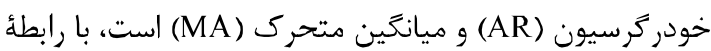
$y_{t}+\sum_{i=1}^{p}\left(a_{i} y_{t-i}\right)=e_{t}+\sum_{i=1}^{q}\left(c_{i} e_{t-i}\right)$

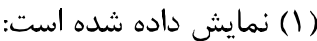

${ }^{3}$ Recursive Least Square Method

${ }^{4}$ Autoregressive-Moving-Avcrage

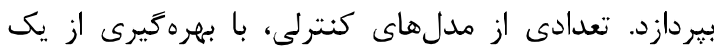
رويكرد ساده به تغيير ابزارهاى كنترل دما، نظير فركانس و ونير

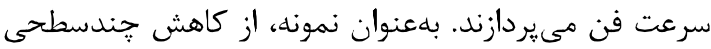
فركانس يردازنده، بدون ويشيشينى ياسخ كنترلى استفاده

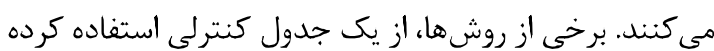

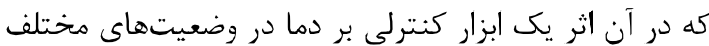

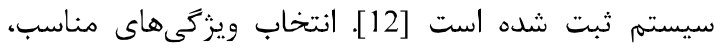

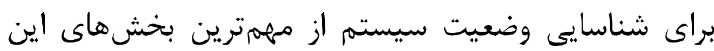
رويكرد است. رويكردهاى ديخر در مديريت دما، مدلى را براى بناي تعيين مقدار مناسب براى هر ابزار كنترلى انتخاب مى كنند

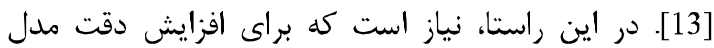
كنترلى، ويزكى هاى مناسب براى آن انتخاب شود.

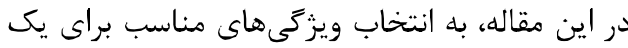

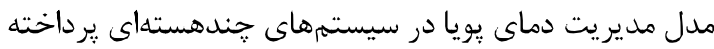

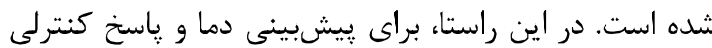
دما، از شبكه عصبى برسيترون جندلايهاى ' (MLP) استفاده

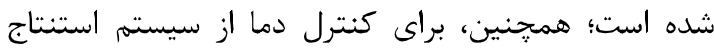

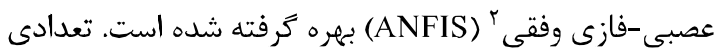
از ورودىهاى مدلها، شامل فركانس يردازنده، سرعت فن،

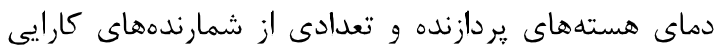

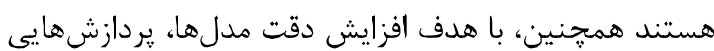
براى توليد ويزَى هاى مناسب براى هر يك از مدلها ارائه

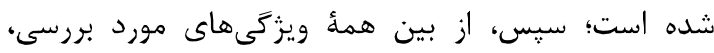

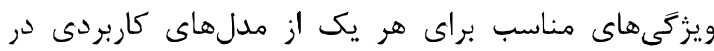

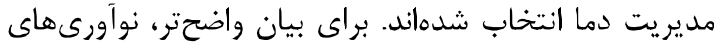

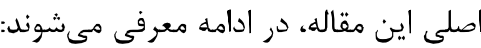

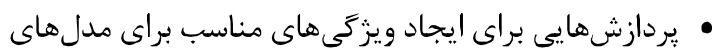

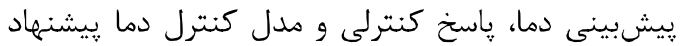
شده است.

• براى هر يك از مدلهاى مورد بررسى، ويزّكىهاى مناسب، در جهت افزايش دقت و كاهش سربار دحاسباتى انتخاب

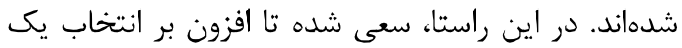

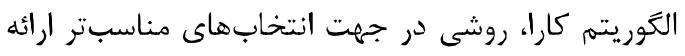
شود. • مدل هاى ييشنهادى، براى فاصلههاى زمانى مختلف مورد

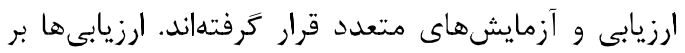
روى يك سيستم קندهستهاى و بدون نياز به سختافزار اضافى انجام مىشوند.

\footnotetext{
${ }^{1}$ Multi-Layer Perceptron

2 Adaptive Ncuro-Fuzzy Inference System
} 
استفاده از رابطة خطى (ب)، از تركيب شمارندههاى كارايى براى تخمين دما استفاده كردهاند [16].

$$
T_{\text {overall }}=w_{\text {const }}+\sum_{i=1}^{22} w_{i} \frac{u_{i}}{t_{\text {total }}}
$$

Suli ير دازنده (

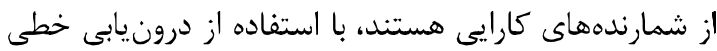
تعيين مىشوند. همجنين، ير دازنده، در حالت بيكارى است.

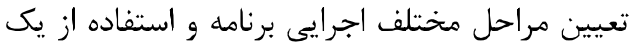

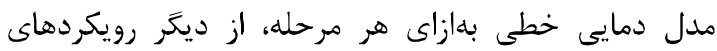

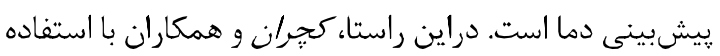

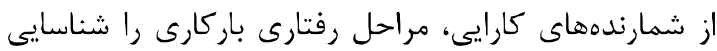

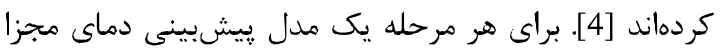

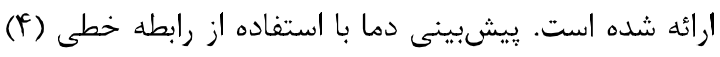

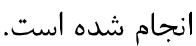

$$
g_{m}[i]=T_{m}[i]-\sum_{n=1}^{N} a_{m n} T_{n}[i-1]-a_{m}^{i d l e}
$$

داى $T_{m}[i]$ مدل از ديد هستأ m هستند.

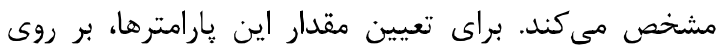

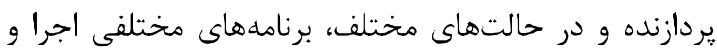

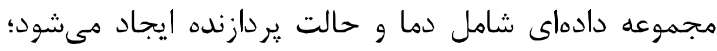

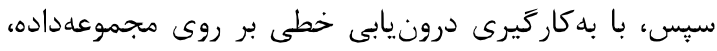

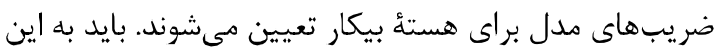

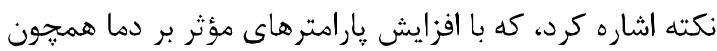
سطوح فركانس، مراحل باركارى و تعداد هستههاى يردازنده،

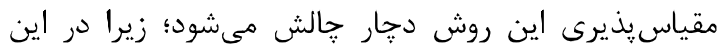

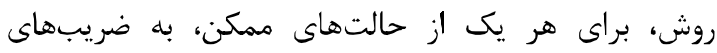
جداكانهاى براى مدل يِيشبينى دما نياز است. تعيين مقدار

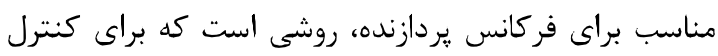

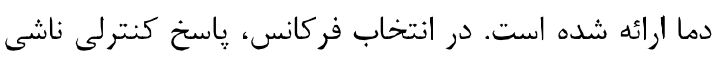

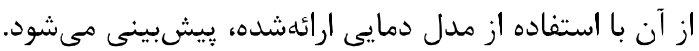
استفاده از دو مرحله فعاليت بالاو فعاليت معمول، براى إئي

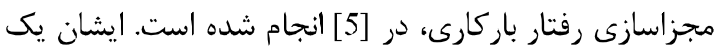

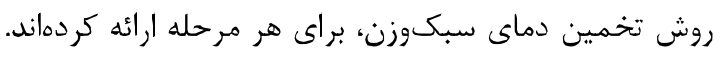

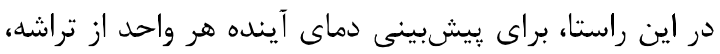

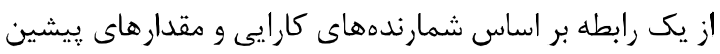

كه در آن

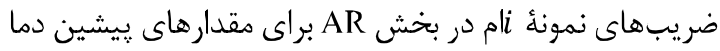
و در بخش MA براى مقدارهاى خطاى يِيشبينى ييشين

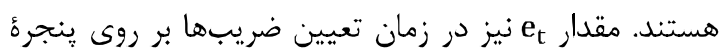

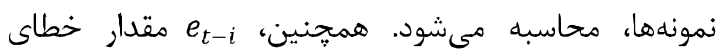

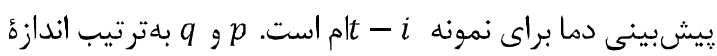

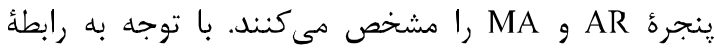

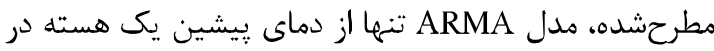

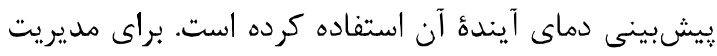

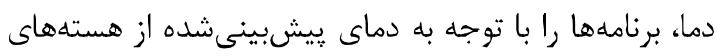
هختلف، زمانبندى مي كنند.

دماى يوياى يك هسته بر روى يك يردازنده

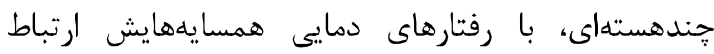

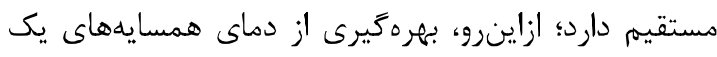

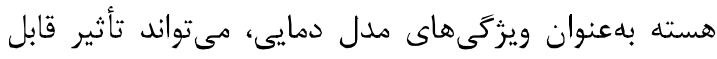

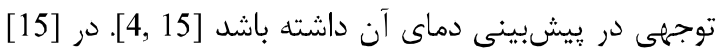
از رابطة (r) براى ييشينى دينى دما استفاده شده است.

$$
T_{i}^{\text {predict }}=\alpha_{i} T_{i}^{\text {core }}+\beta_{i} I_{i}^{\text {in }}+\gamma_{i} I_{i}^{\text {nb }}
$$

كه در آن Sore و و همجزين ضريبهاى خطى، بر روى اطلاعات ثبتشده از دماى هستهای هاى يردازنده،

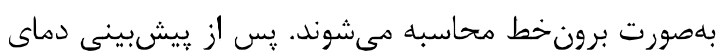

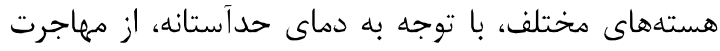

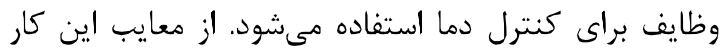

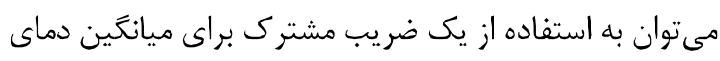

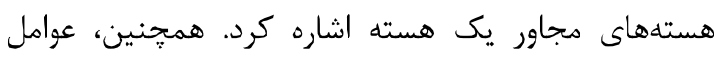
مؤثرى همجيون رفتار بار كارى، در اين كار ناديده كرفته شده

از ديخر ويزّكىهاى مؤثر بر دماى يردازنده كه در

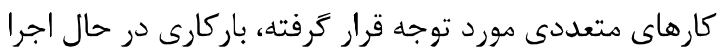

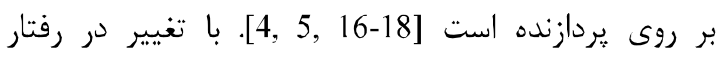

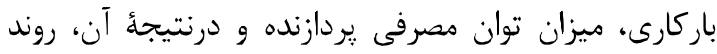
تغيير دماى يردازنده دكركون مىشود [17,18]. رفتار برنامه

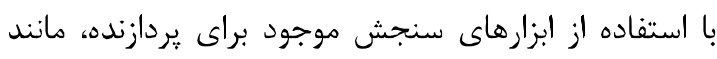

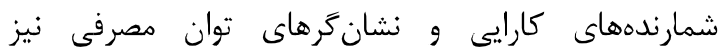
اندازمخيرى شده است [16]. در اين راستا، كومار و همكاران بان توان 
جمعآورىشده، براى يِشبينى توان مصرفى هسته پردازنده

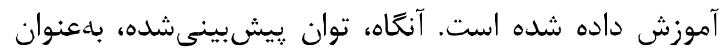

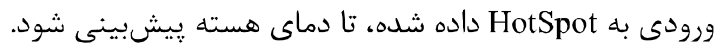

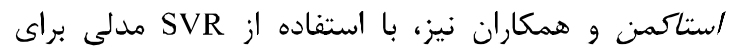

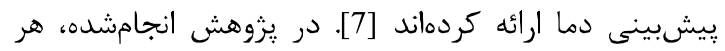

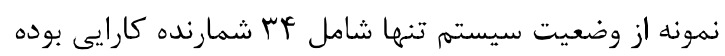

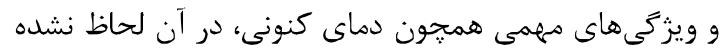

رويكردهايى كه تاكنون براى بِيشبينى دما بِيشنهاد

شدهاند، براى پيشبينى پاسخ كنترلى نيز مورد استفاده قرار

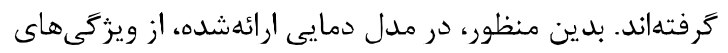
يكسان براى يبشبينى دما و ياسخ دمايى استفاده مىشود.

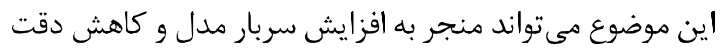

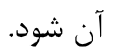

اغلب مدلهاى كنترل دما، براى تعيين مقدار مناسب

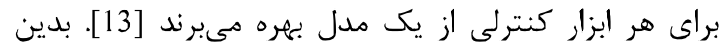

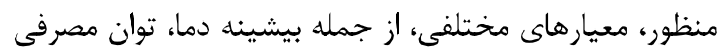

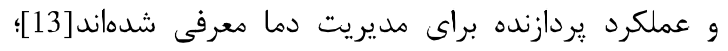

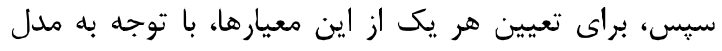

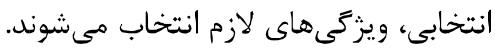

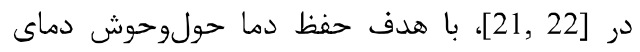
حدآستانه و كاهش توان مصرفى، با بهرهَيرى از

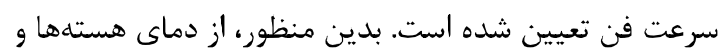

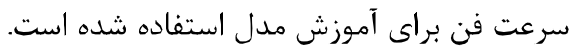

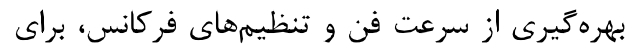
مديريت دما در كارهاى مختلفى استفاده شده است [13 $[12,13$.

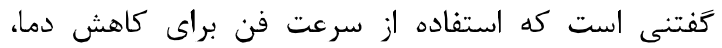

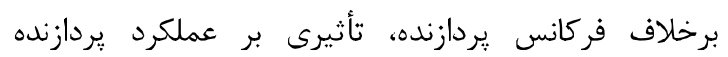

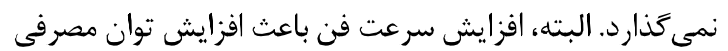

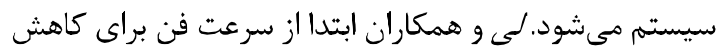

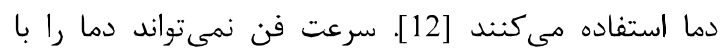

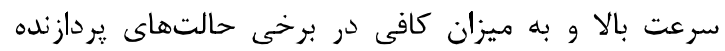

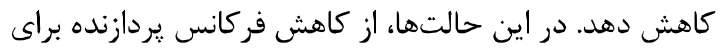

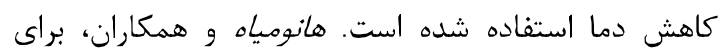

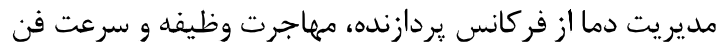

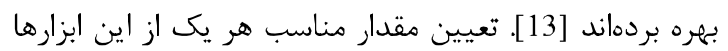
بلهصورت مداوم و در بازههاى زمانى كوتاهمدت انجام ميى مقدود. در تمامى روشهاى مدلسازى اشارهشده، تعدادى از

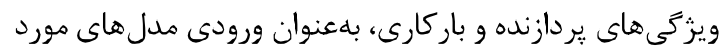

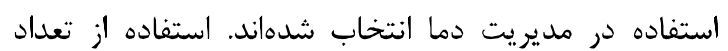

دماى آن بهره بردهاند. براى تعيين ضرايب رابطه، از ركرسيون

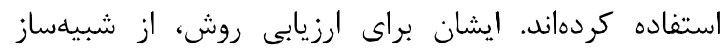

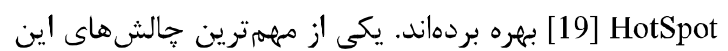
كار، نياز به داشتن دانش معمارى يردازنده، براى بيكربندى إنى بردي ابزار HotSpot است.

شبكة عصبى MLP، يكى از مهمترين مدلها در

بيشبينى دما بوده كه در مقالههاى متعددى مورد ارزيابى قرار

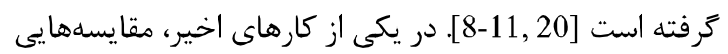

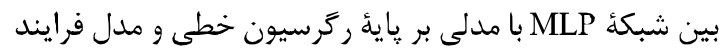
كَوسى انجام شده است [20]. نتايج ارائهشده، دقت بالائ مدل دئل

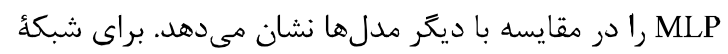

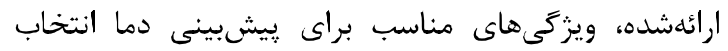

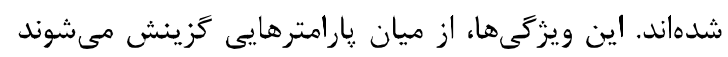

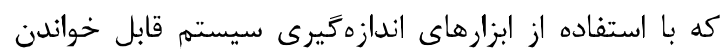

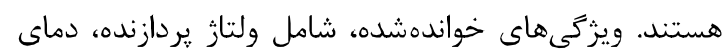

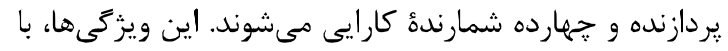

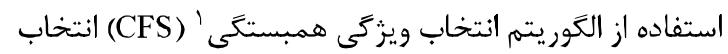

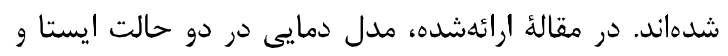

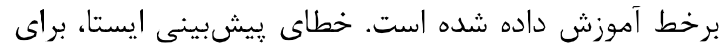

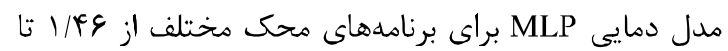

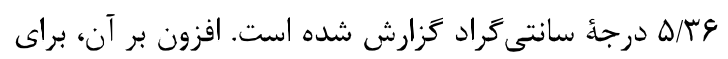

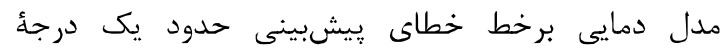
سانتى كراد كَزارش شده است.

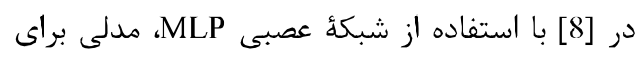
بيشبينى دماى بيك يك هستئ بردازنده، ارائه شده است.

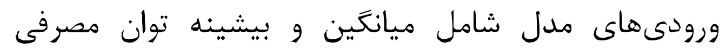

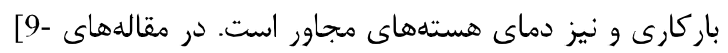

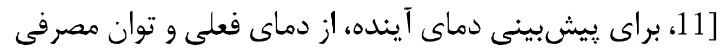

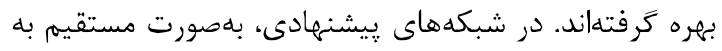

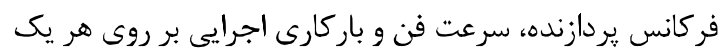
از هستههاى يردازنده توجه نمى شوداد

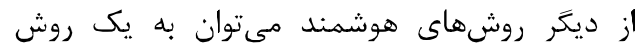

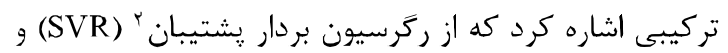

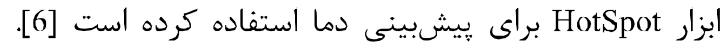
ابتدا يك مجموعه داده شامل شمارندههاى كارايى و ميزان

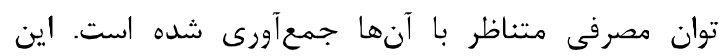

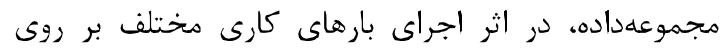

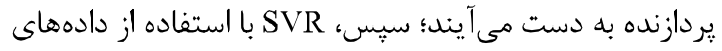

\footnotetext{
${ }^{1}$ Correlation Feature Sclection

${ }^{2}$ Support Vector Regression
} 
توجهى از راهحلهاى DTM براى هر يك از اين مدلها،

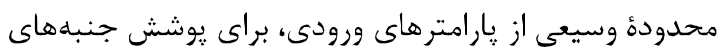

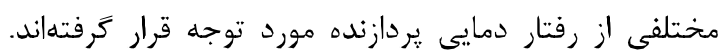

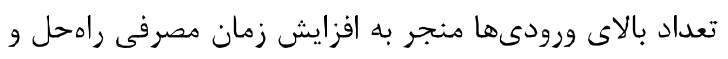

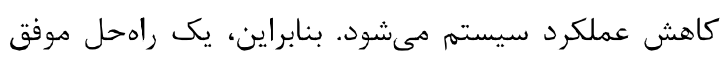

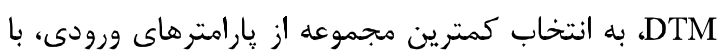
بيشترين يوشش ممكن مسئله، نياز دارد.

\section{r-r- انتخاب ويزگ}

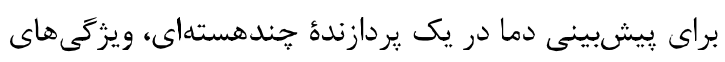

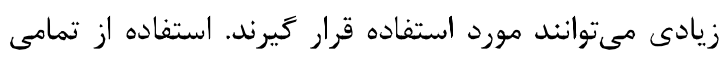

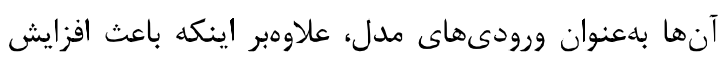

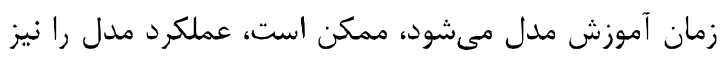
كاهش دهد. شيوههاى مختلفى براى انتخاب ويثزى مانى وجود

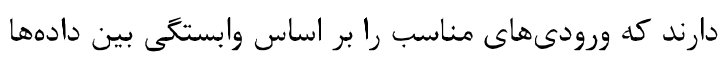

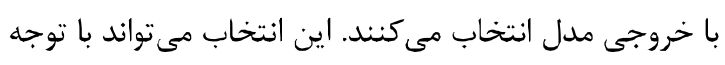

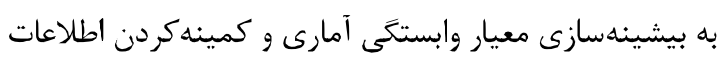

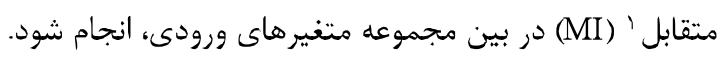

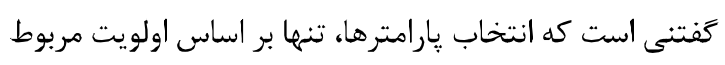

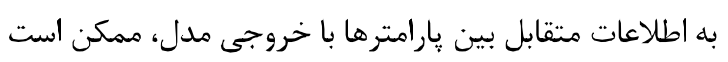

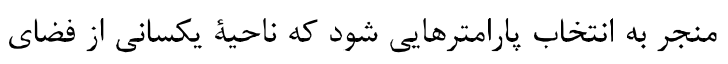

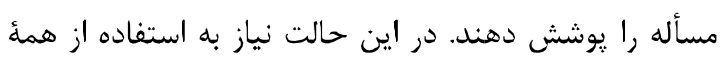
آن بارامترها نيست.

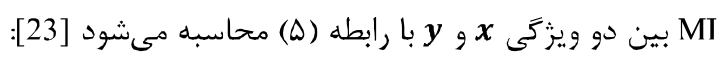

$$
I(x ; y)=\iint p(x, y) \log \frac{p(x)}{p(x) p(y)} d x d y
$$

مثفرهاي x متغيرهاى x ، y و وقوع همزمان آنها است.

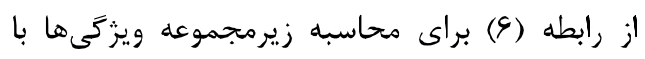

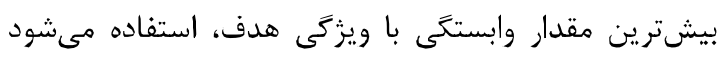

$$
\max V_{I}(S, h), \quad V_{I}=\frac{1}{|S|} \sum_{i \in S} I(i, h)
$$

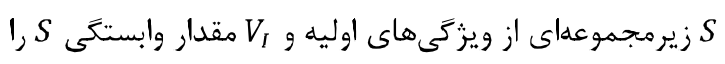
با ويزَّى هدف h نشان مى دهد.

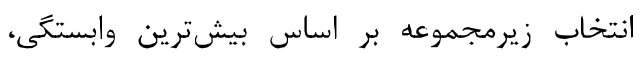

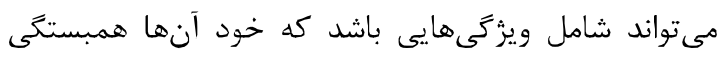

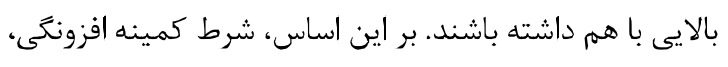

\footnotetext{
${ }^{1}$ Mutual Information
}

زيادى ويزگىى، حتى اكر منجر به كاهش دقت مدل نشود،

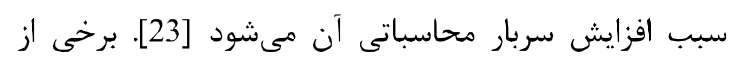

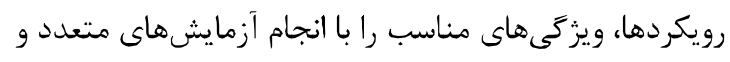

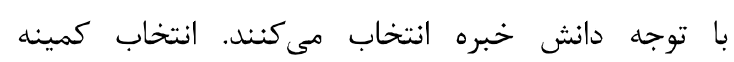

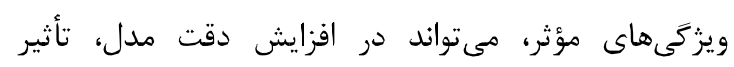

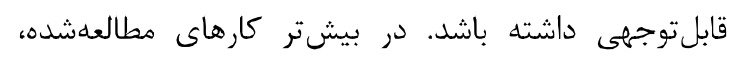

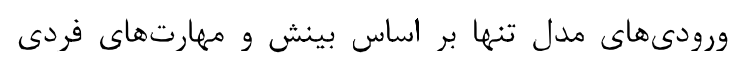
يزوهش

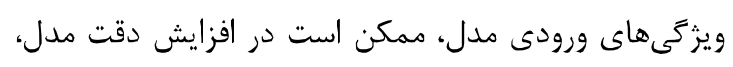
تأثير قابلتوجهى داشته باشد.

\section{ب- تعاريف اوليه}

در اين بخش، ابتدا به معرفى فضاى مسأله يرداخته مىشودي؛

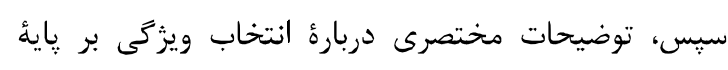

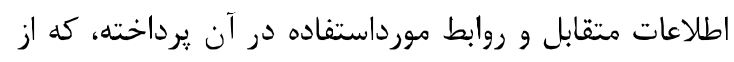
بخشهاى اصلى روش بيشنهادى است.

\section{1- 1- - توصيف مسأله}

يك يردازنده جندهستهاى بيش از يك هستهُ يردازشى دارد.

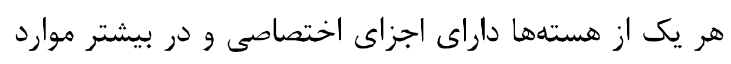

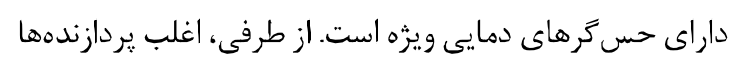

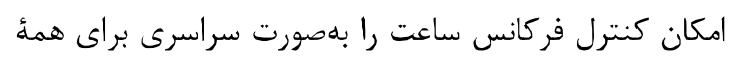

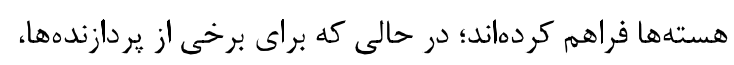

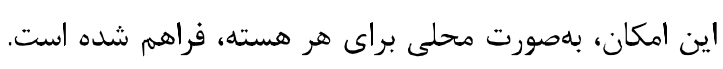

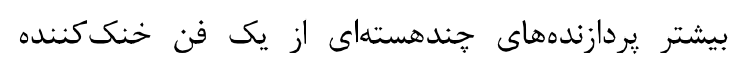

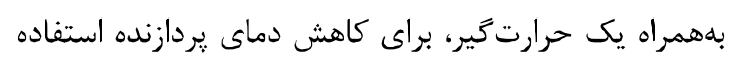

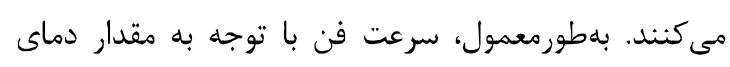

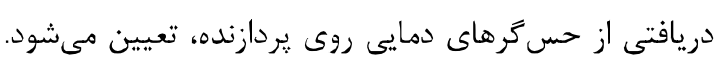

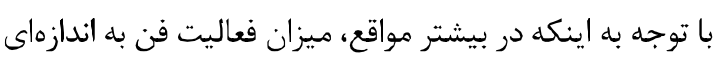

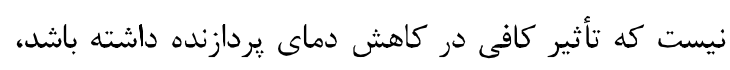

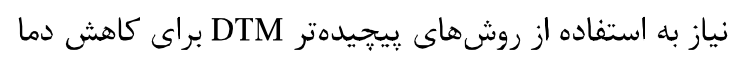

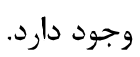

در يك رويكرد از روشهاى مديريت دما، از يك مدل

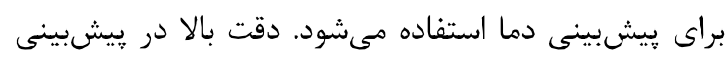

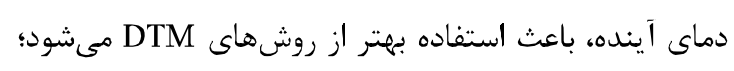

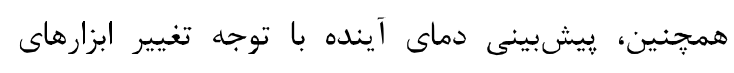

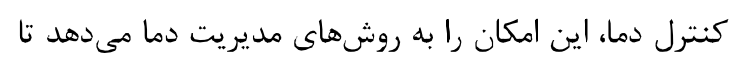

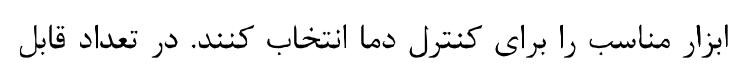


با هدف افزايش دقت مدلها، با يردازشهاى ييشنهادى، ايجاد

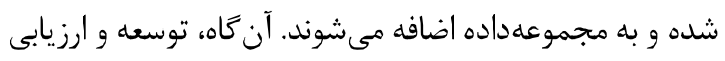

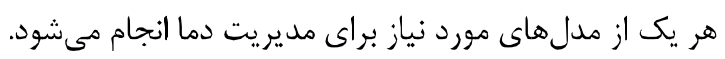

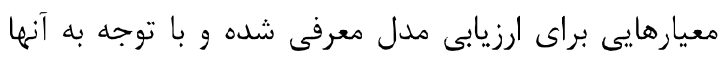

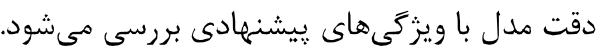

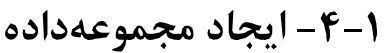

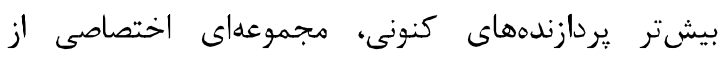

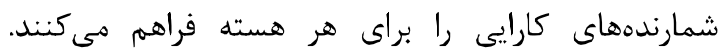

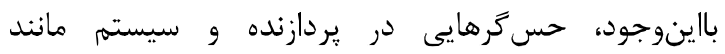

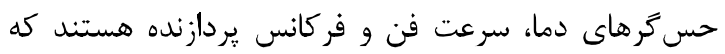

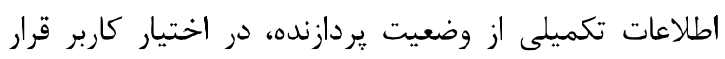

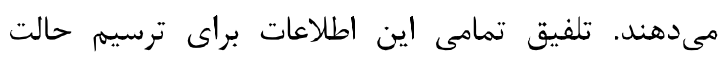

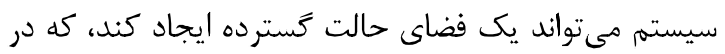
آن احتمال رويداد تمادى حالتها باهم يكسان نباشد.

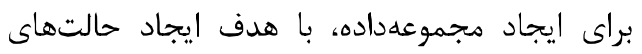
متنوع در سيستم، آزمايشى انجام شده كه در آن تركيبهاي إنهاد

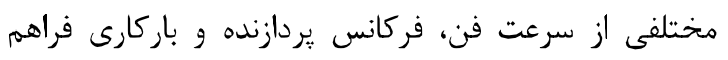

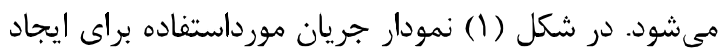

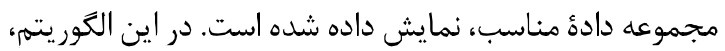

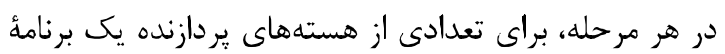

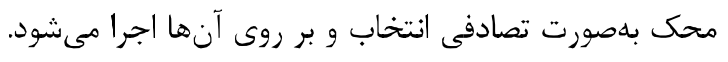
در هر مرحله، تمامى تركيبهاى سرعت فن و ميزان فركانس ندانس

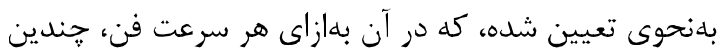

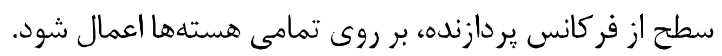
ترتيب انتخاب سطوح فركانس، بهصورت تصادفى تعيين شده تا تغيير حالتهاى تصادفى فر كانس در آزمايش منعكس شون شودي؛

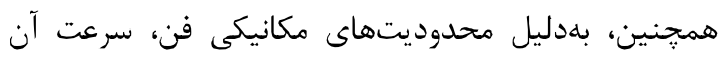

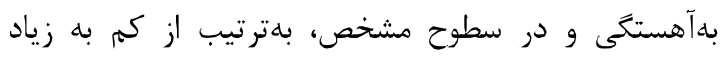

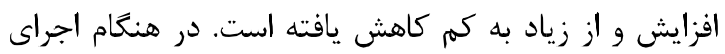

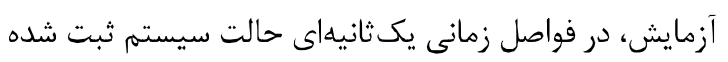

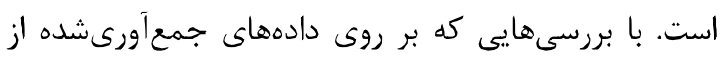

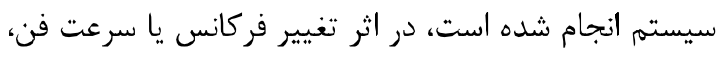

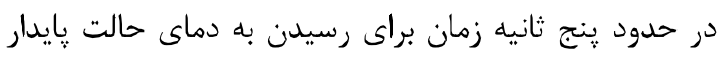

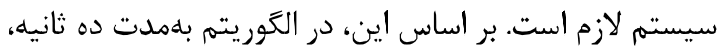

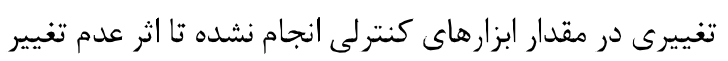

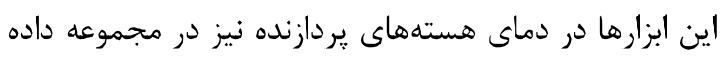

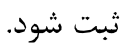

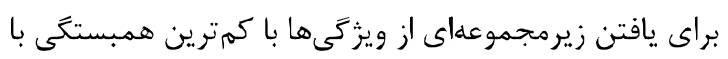

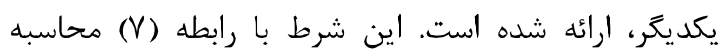

مىشود [23].

$\min W_{I}(S), \quad W_{I}=\frac{1}{|S|^{2}} \sum_{i, j \in S} I(i, j)$

ميانكين MIWI بين ويزگكى ها در زيرمجموعه SI است.

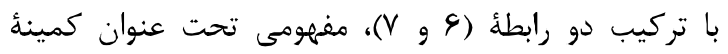

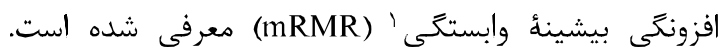

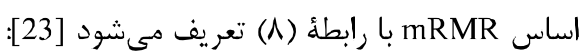
$\max \varphi(V, W), \varphi=V-W$

عملكرى براى تركيب روابط بيشينه وابستخى و كمينة افزونكى است.

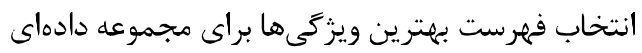

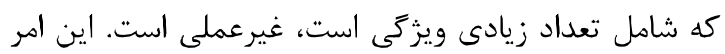

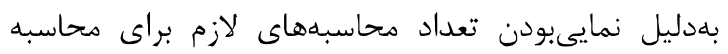
max $\varphi(V, W)$

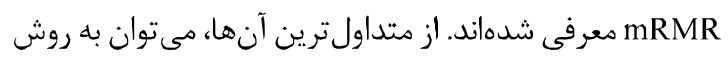

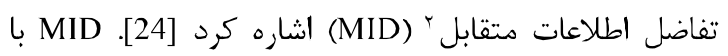
رابطة (9) محاسبه مىشود.

$\max _{i \in \varphi(S)}\left[I(i, h)-\frac{1}{|S|} \sum_{j \in S} I(i, j)\right]$

از مزيتهاى استفاده از روابط تخمين mRMR مى توان

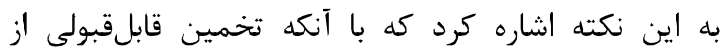

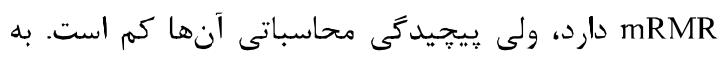

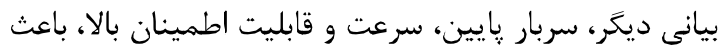

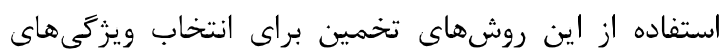
مناسب شده است.

\section{F - روش ييشنهادى}

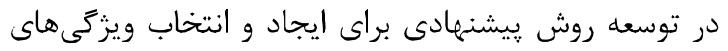

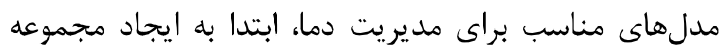

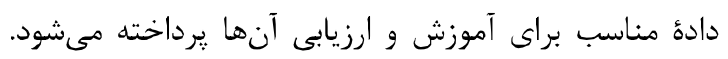

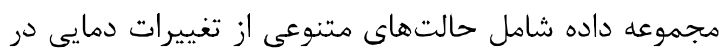

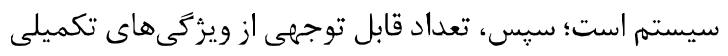

${ }^{1}$ Minimum Redundancy Maximum Relevance

${ }^{2}$ Mutual Information Difference 


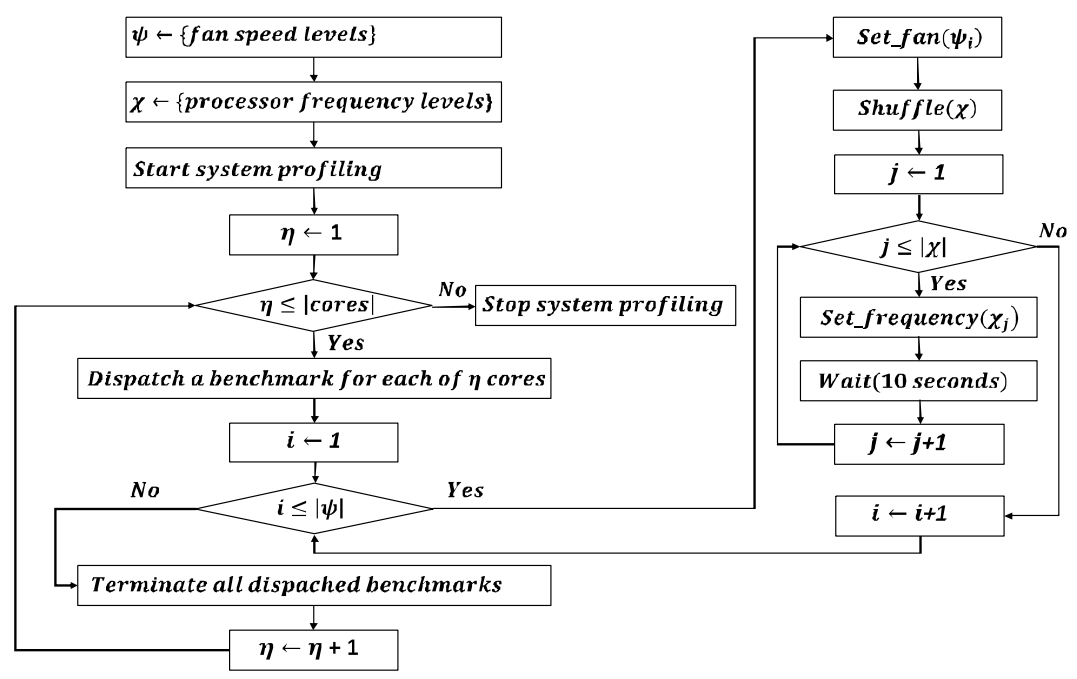

(شكل -1): نمودار جريانى ايجاد يك مجموعهدادهُ مناسب براى آموزش مدلهاى مديريت دما

(Figure-1): The flowchart of creating appropriate dataset for training the thermal management models

يارامترها، براى مدلهاى يِيشبينى پاسخ كنترلى و كنترل دما

مناسبند.

در اين يثوهش، با انجام بردازشهايى، مجموعه دادهاى

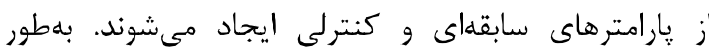

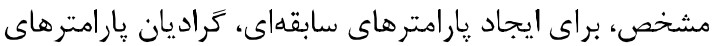

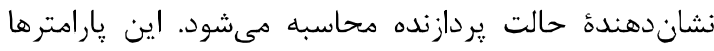
شامل دماى هستهها و شمارندههاى كارايى است. كَراديان يارامتر p با فاصلئ d با رابطة (• (1) محاسبه مىشود.

$$
\nabla p_{t}(d)=\frac{p_{t}-p_{t-d}}{d}
$$

p مقدار يارامتر در نمونئ t $t$ و بارامتر در d نمونهٔ قبلى است. درواقع گراديان نخست،

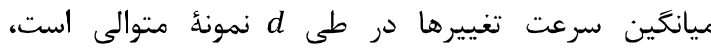

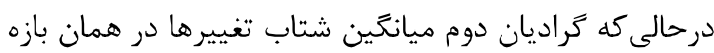
است. در اين مقاله، كراديانهاى يارامترهاى اوليه، با فاصلههاى دراي زمانى مختلف با مقادير اوليهشان بهعنوان ويزگكىهاى سابقهاى دانى

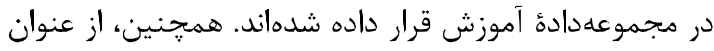
كراديانهاى آينده براى ايجاد پارامترهاى كنترلى استفاده مىشود. تراديان آيندة يارامتر كنترلى

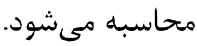

$\hat{\nabla} p_{t}=p_{t+1}-p_{t}$

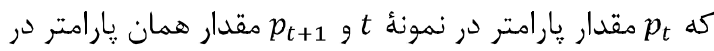
نمونd بعدى است. واضح است كه كراديان آينده تغيير مورد

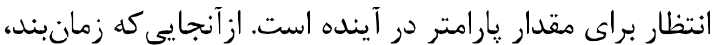

\section{F- F-}

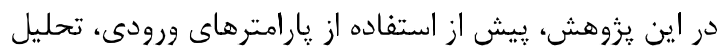

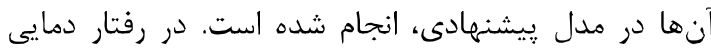
يردازنده، مشاهده مىشود كه ترتيب نمونهها در مجموعهدادة دئ

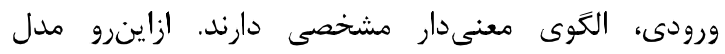
بيشبينى دما، بر وابستكى بين نمونههاى متوالى تكيه داشته و هر نمونه مىتواند با يك سرى نمونههاى قبلى، بيشيشينى

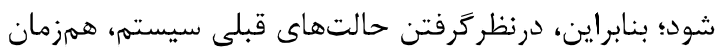

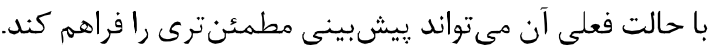

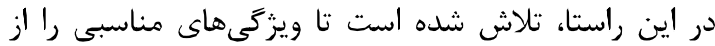

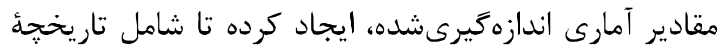

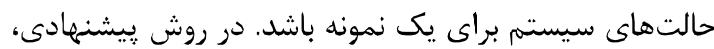

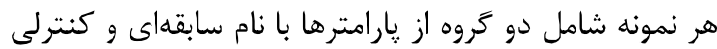

يارامترهاى سابقهاى، تكيه بر رفتار سختافزارى بردازنده و نرمافزار در حال اجرا روى آن دارد. بلعنوانمثال، اندازهيرىهاى حسكرهاى دمايى و مقادير شمارندهائ

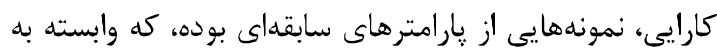
مدل يردازنده و برنامئ در حال اجرا هستند. يارامترهاى نداى سابقهاى مورد نياز براى مدل بيشبينى دما هستند.

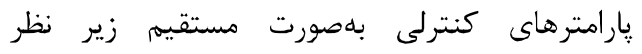
سيستمعامل هستند. بيشتر، مقدار يارامترهاى كنترلى زمانى تغيير مى كنند كه زمانبند سيستمعامل واكنشى را در جهت

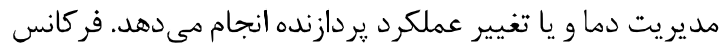

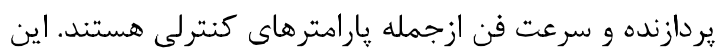


شامل تعيين مقدار هر يارامتر در بازٔ بين صفر و يك است، از رابطة ( ا ( ) استفاده مىشود:

$$
\eta_{i, j}=\frac{v_{i, j}-\min \left(V_{j}\right)}{\max \left(V_{j}\right)-\min \left(V_{j}\right)}
$$

Z كه نمونه در مجموعهداده است. يس لِ

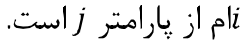

\section{ץ-F - توسعة مدل بيشبينى دما}

مدل بيشنهادى، MLP سهلايه بوده، كه در شكل (T) نمايش

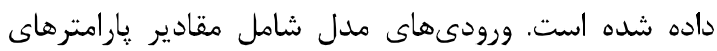
سابقاى دماى هسته، دماى هستههاى مجاور و مقدارهاى

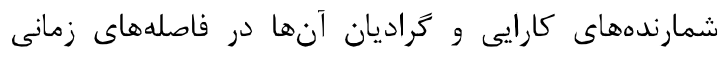

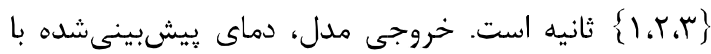

مقادير آيندة اين پارامترها را تنظيهم مى كند، محاسبة اين

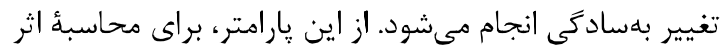
تغييرات فركانس و سرعت فن بر دما، استفاده مىشود.

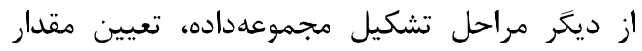
هدف براى هر نمونه است. تعيين مقدار هدف با توجه به فاصلة مطلوب پِيشبينى دما، انجام ميشود. بنابراين،

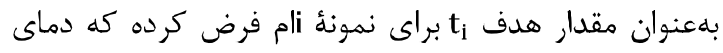

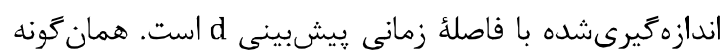
كه مشخص است، مقدار d بايد با توجه به فاصله زمانى نداني

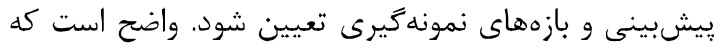

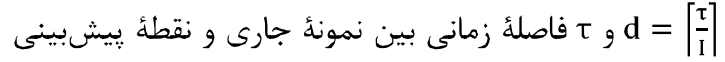

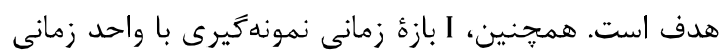

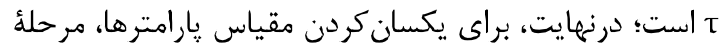

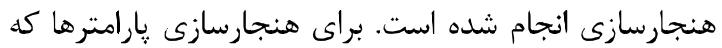
فاصلة d d است

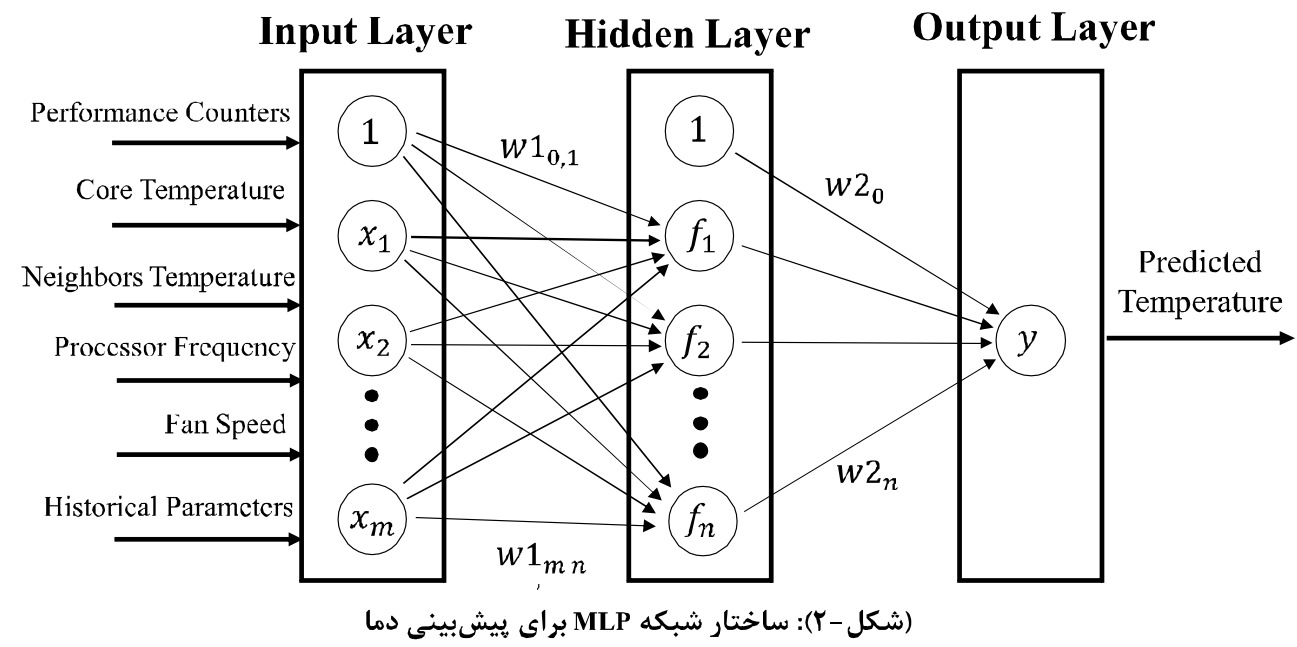

(figure-2): The MLP structure for predicting temperature

مطلق خطـا' (MAE)، انحراف معيار قدرمطلق خطـ؟ و درصد خطاى بيش از سه درجه استفاده شده است. $M A E=\frac{1}{N} \sum_{i=1}^{N}\left|t_{i}-y_{i}\right|$

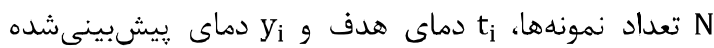
براى نمونئ أام است. همجنين SDAE با رابطة (4 ( ) محاسبه

مى شود: - مي:

${ }^{1}$ Mean Absolute Error

${ }^{2}$ Standard Deviation Absolute Error
براى ارزيابى هدل، ابتدا جايگشتى بر روى دجموعه

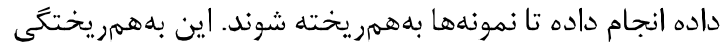

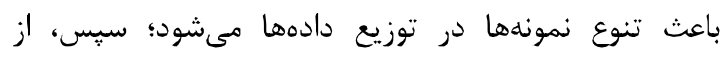
اعتبارسنجى متقابل KK تايى جهارده استفاده مىشود. در اين رويكرد، دادهها به K دسته متمايز تقسيمبندى شده و دقت مدل در K مرحله محاسبه مىشود. در هر مرحله، K-1 دسته

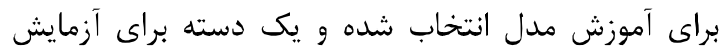
استفاده مىشود؛ درنهايت، از خطاهاى همدٔ مراحل براى دحاسبة خطاى مدل استفاده مى شود. براى بررسى دقت ييشبينى، از معيارهاى ميانگين قدر 
اولويتبندىشده با روش MID انتخاب شوند، نتيجهُ ارزيابى، تحت عنوان حالت سوم در شكل (f) نمايش داده شده است.

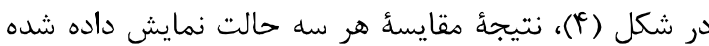

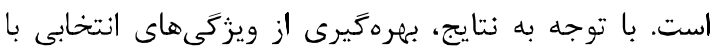

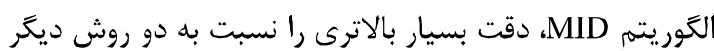

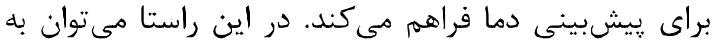

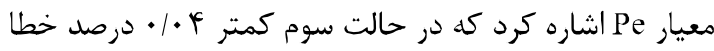

\section{د}

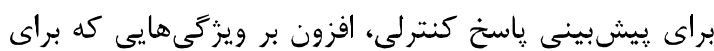

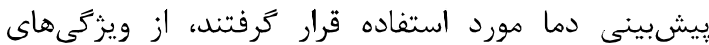

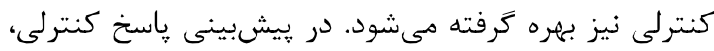

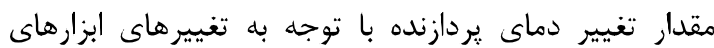

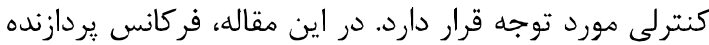

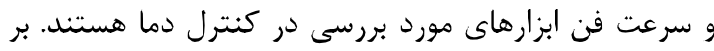

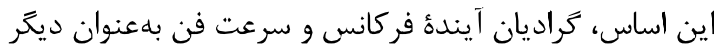

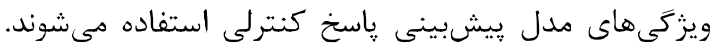

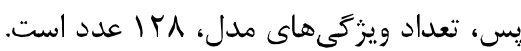

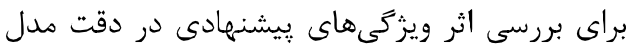

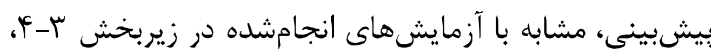
در سه حالت مختلف دقت مدل محاسبه مىشود. در حالت نخست، از ويزگى هايى بهعنوان ورودىهاى مدل بهره كرفته

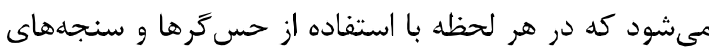

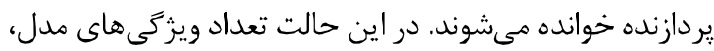
نوزده عدد است. در حالت دوم، ويزّكى هاى سابقهاي و كنترلى

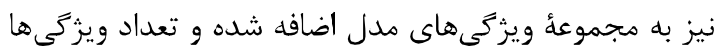

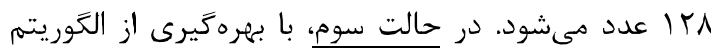

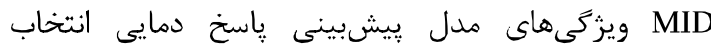

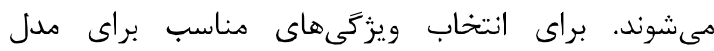
يِيشبينى راسخ كنترلى از الكَوريتم نمايش دادهشده در شكل

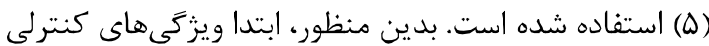

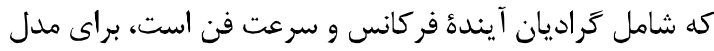

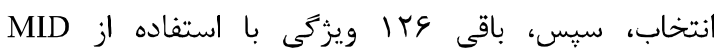

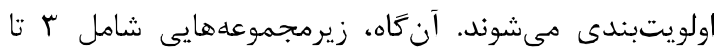

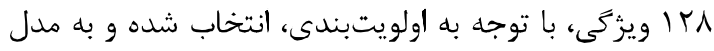

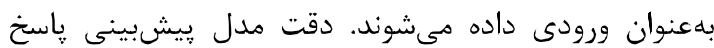
كنترلى محاسبه شده و در شكل (9) نمايش داده شده است.

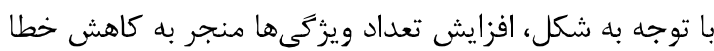

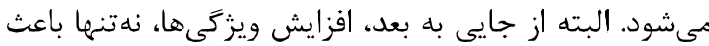

كام، زيرمجموعههايى شامل |

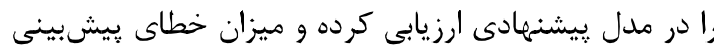

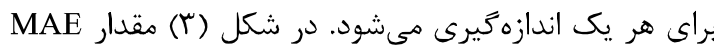

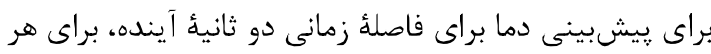

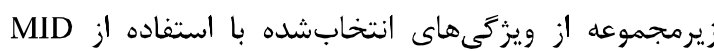
نمايش داده شده است. بايد توجه داشت كه براى استفاده از

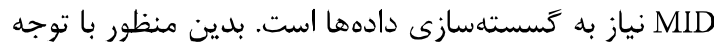
به مقادير بين كمينه و بيشينٔ دما در سيسته، تعداد بازهها تعيين مىشود. بلعنوانمثال براى دماى كمينه سى و بيشينه

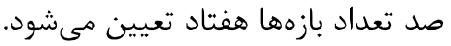

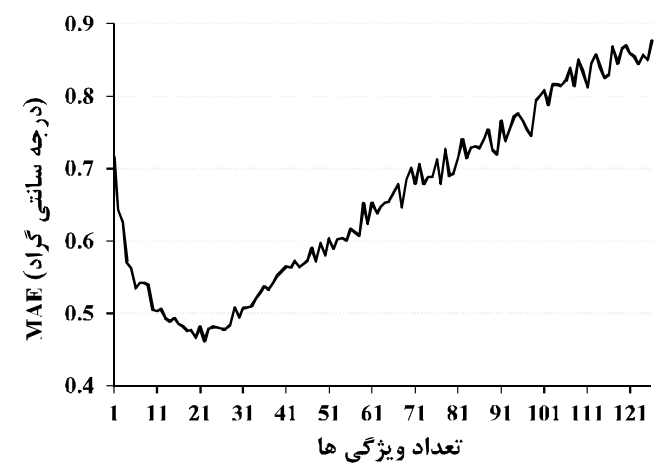

(شكل-"ّ): اثر افزايش تعداد ويثخى ها در دقت مدل هيشبينى دماى دو ثانيئ آينده

(Figure-3): The effect of increasing the number of features on the accuracy of thermal prediction for the next 2 seconds

$$
\begin{aligned}
& \text { حالت اول } \\
& \text { حالت دوم = } \\
& \text { حالت سوم: }
\end{aligned}
$$

2.13
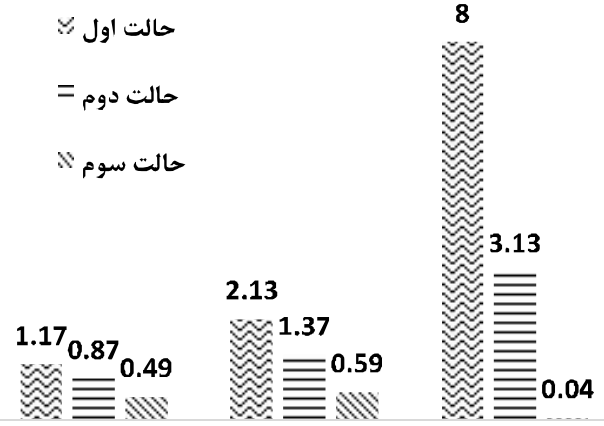

$\operatorname{MAE}\left({ }^{\circ} \mathrm{C}\right) \quad \operatorname{SDAE}\left({ }^{\circ} \mathrm{C}\right) \quad \operatorname{Pe}(\%)$

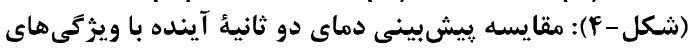

$$
\text { مختلف }
$$

(Figure-4): Comparing the using different features for thermal prediction for the

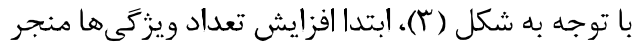

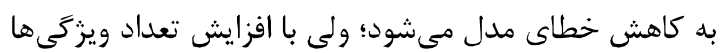

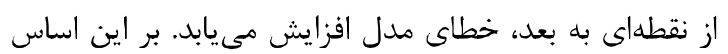

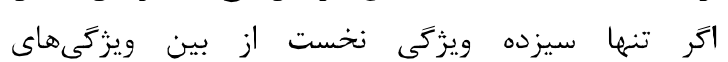




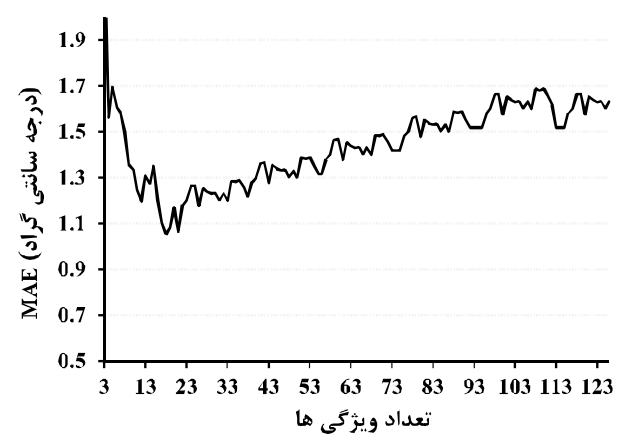

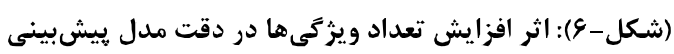
ياسخ كنتر لى دو ثانيةٌ آينده

(Figure-6): The effect of increasing the number of features on the accuracy of control response prediction for the next 2 seconds

$$
\text { حالت حالت دالت سوم }
$$

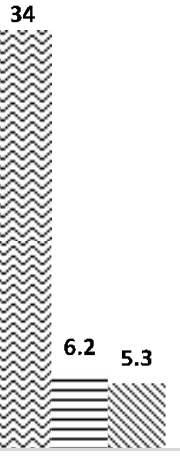

4.3

$4.04 \quad 4.6$

$\approx \approx 1.41 .1$

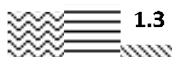

$\operatorname{Pe}(\%)$

MAE $\left({ }^{\circ} \mathrm{C}\right)$

SDAE $\left({ }^{\circ} \mathbf{C}\right)$

(شكل - (V): مقايسه بيشبينى ياسخ كنترلى دو ثانيئ آينده با

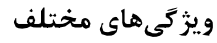

(Figure-7): Comparing the using different features for control response prediction for the next 2 seconds

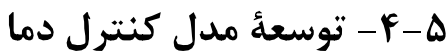

در اين بخش، به انتخاب ويزَّىهاى مناسب براى كنترل دماى يردازنده يرداخته مىشود. در اين مقاله، از دو ابزار فركانس

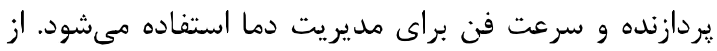

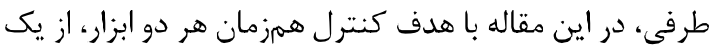
مدل براى تعيين مقادير آنها استفاده مىشود. كَفتنى است

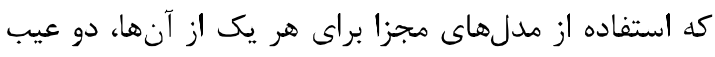

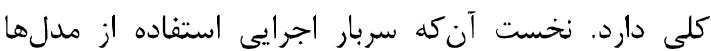

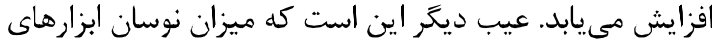

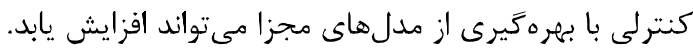

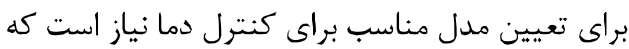

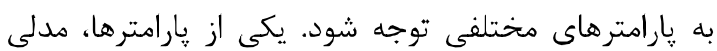

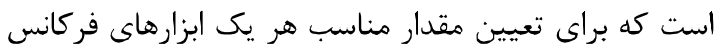

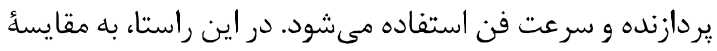

افزايش سربار محاسباتى مدل شده، بلكه منجر به كاهش دقت

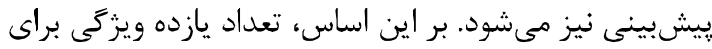

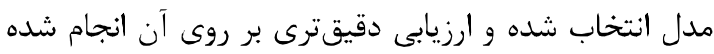

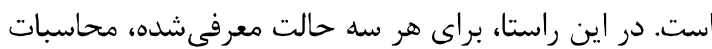
مربوط به معيارهاى ارزيابى، شامل MAE، SDAE و Pe انجام شده و در شكل (V) نمايش داده شده است. از ديكر معيارهاى إنائ

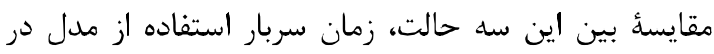
زمان اجرا است. در حالت نخست كه از نوزده ويزّكى استفاده مىشود، زمان استفاده از مدل در هر ثانيه

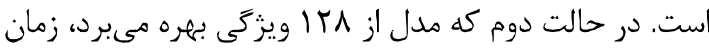

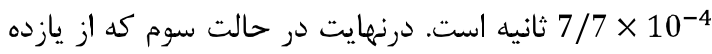

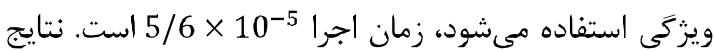

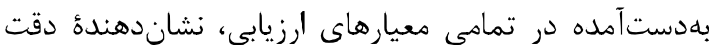

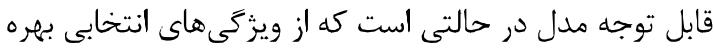

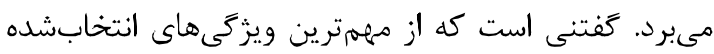

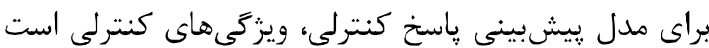
كه باعث افزايش قابل توجه دقت مدل مىشود.

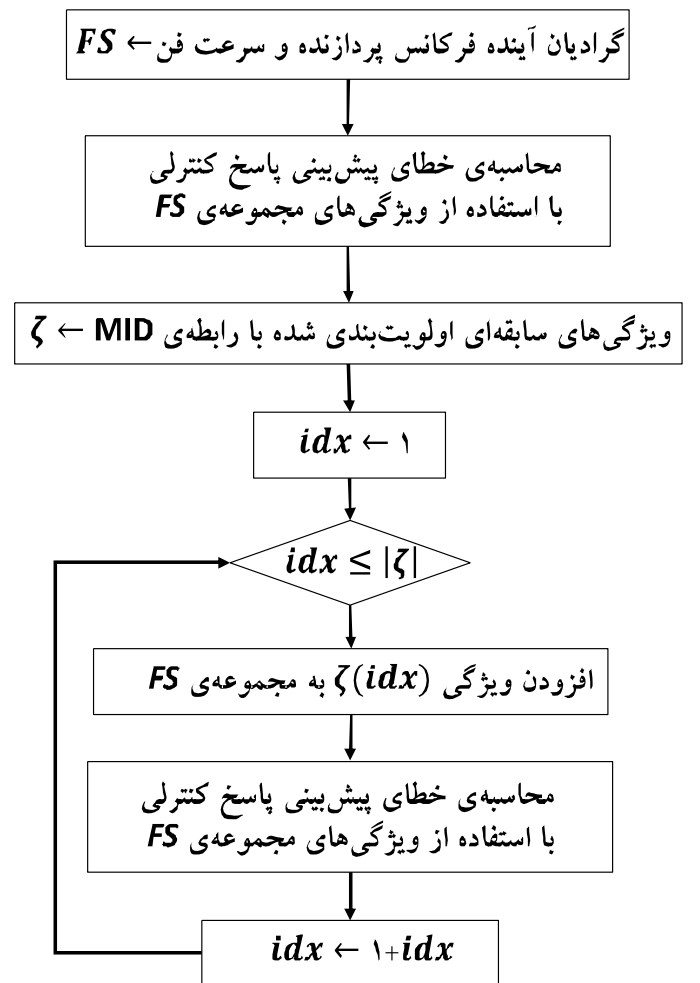

(شكل -ه): الكَور يتهم ييشنهادى براى انتخاب ويزَّى هاى مناسب براى مدل ياسخ كنترلى

(Figure-5): Proposed algorithm to select the appropriate features for the control response model 


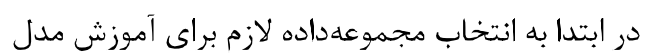

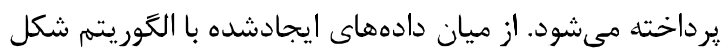

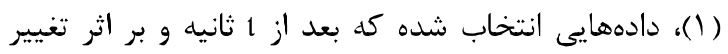

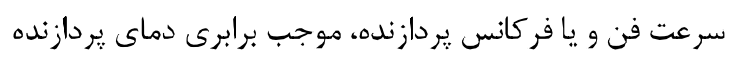

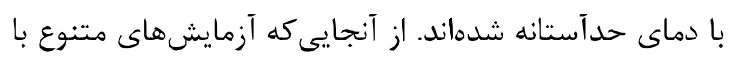

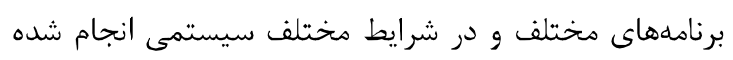

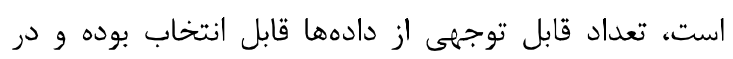

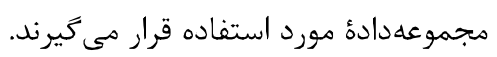

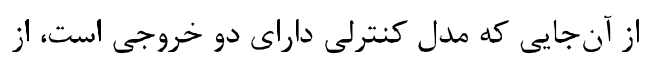

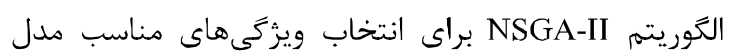

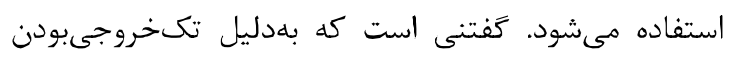

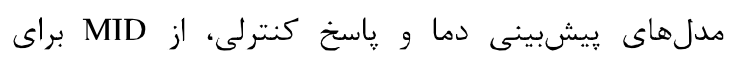

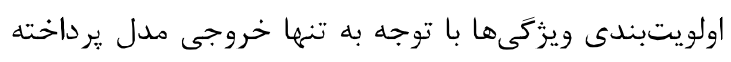

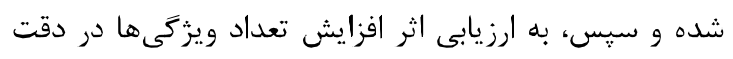

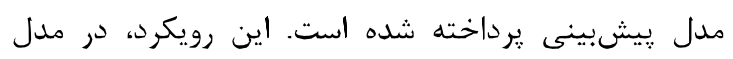

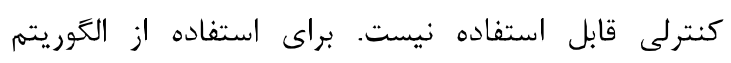

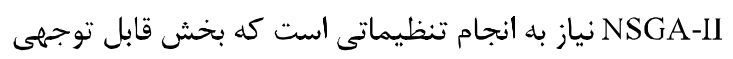

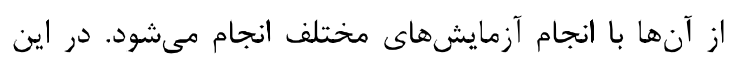

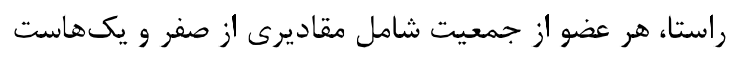

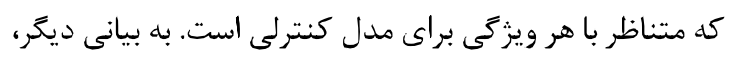

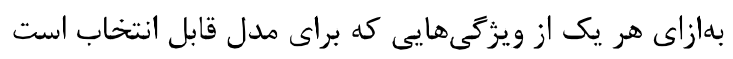

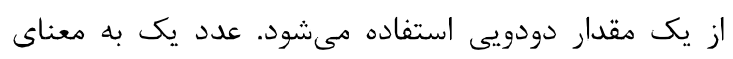

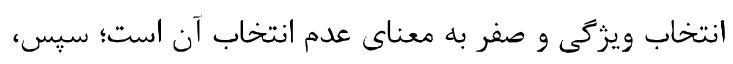

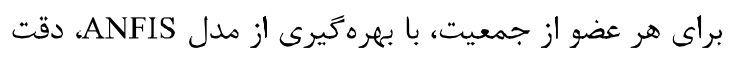

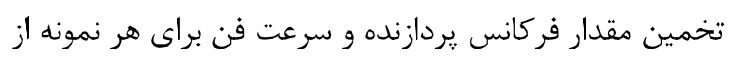

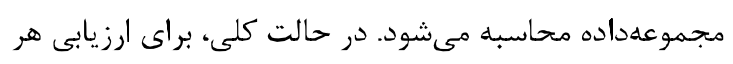

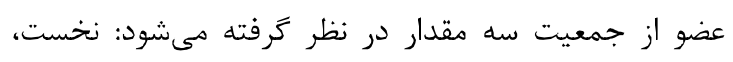

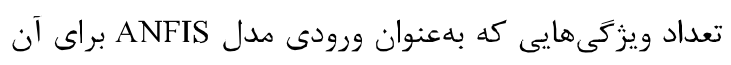

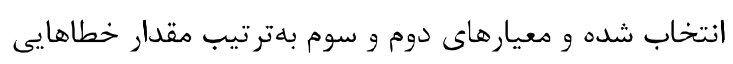

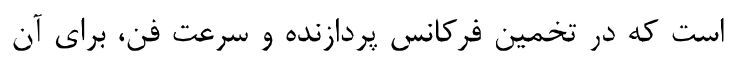

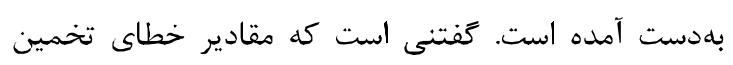

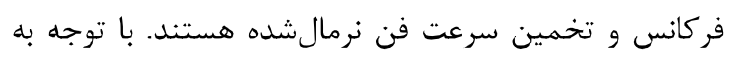

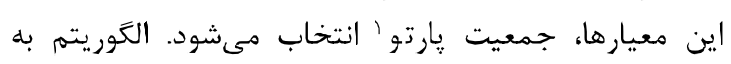

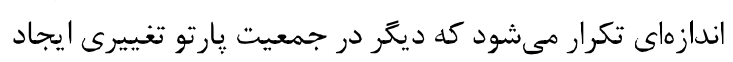

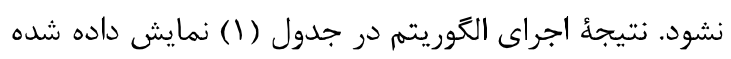

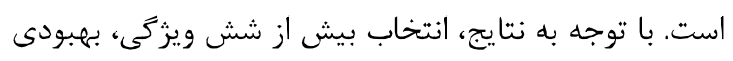

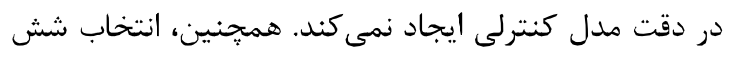

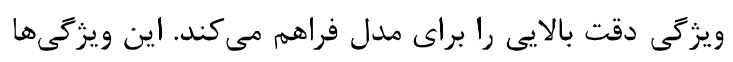

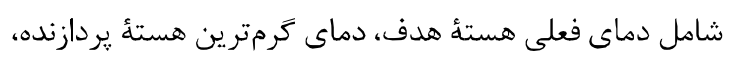

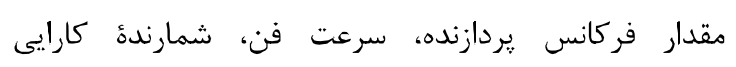

CYCLES

${ }^{1}$ pareto
مدل هاى مختلفى نظير ANFIS،MLP ير داخته شده است. از

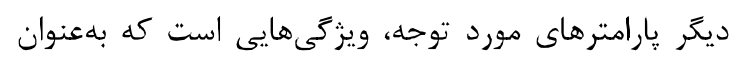
ورودى مدل بايد انتخاب، تا دقت بالايى از مدل كنترلى هائ حاصل شود. ييشتر، براى مديريت دما، از مدل ANFIS در جهت

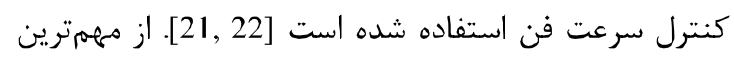

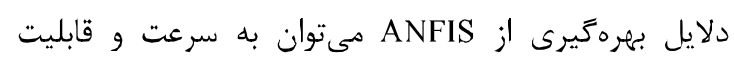

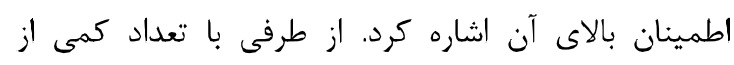

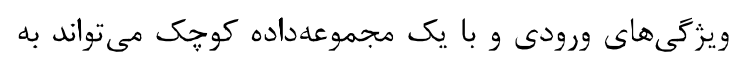

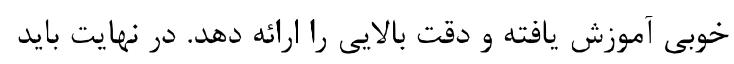

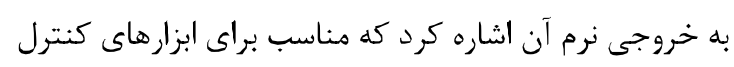

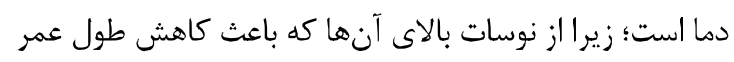

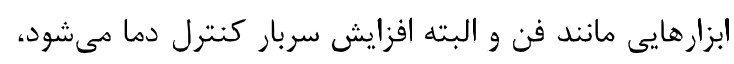

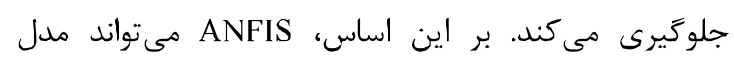
مناسبى براى كنترل دماى بردازنده باشد.

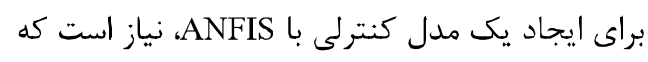

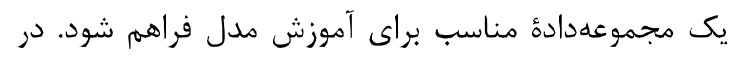

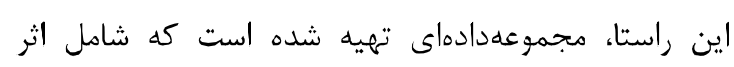

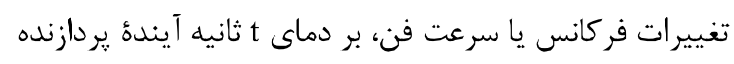

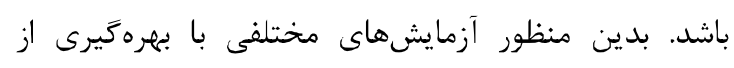

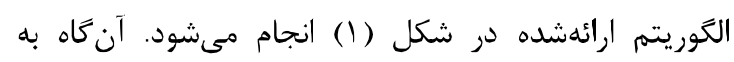

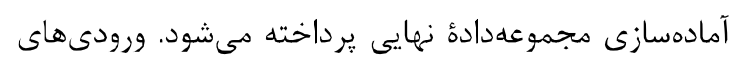

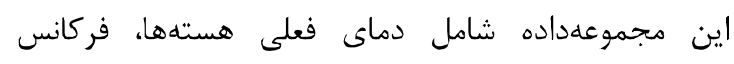

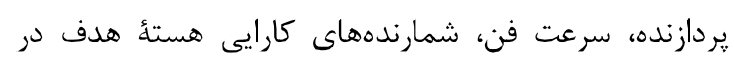

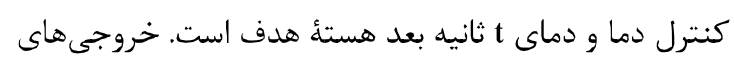

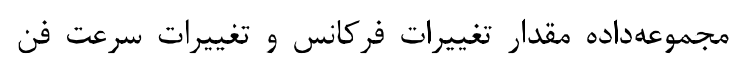

براى ايجاد مدل كنترل دما، ابتدا به انتخاب ويزَّى هاى

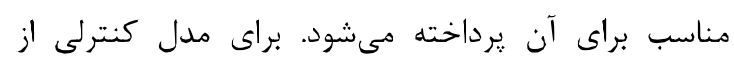

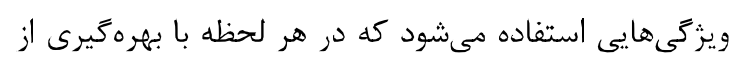

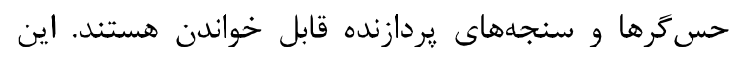

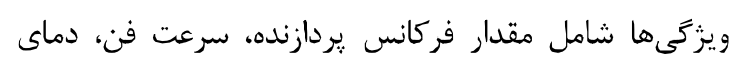

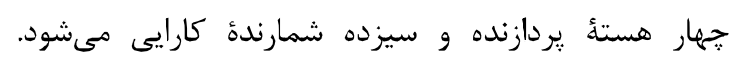

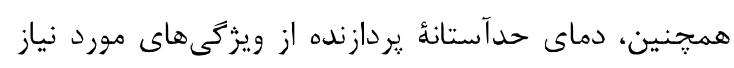

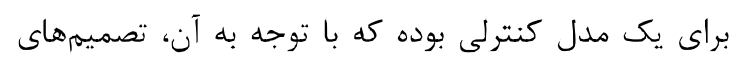

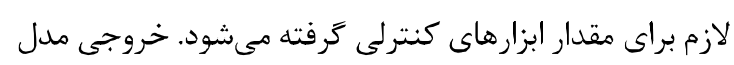

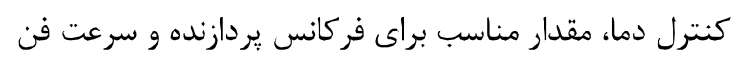

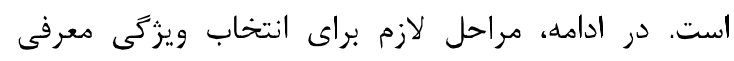
مىشوند. 
نتيجههاى بهدستآمده از آزمايشهاى مختلف، براى ايجاد

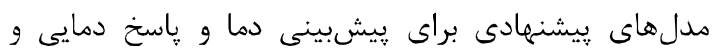

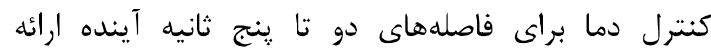
مىشوند.

ه-1 - آنظيمهاى آزمايشغاهى آزمايشها بر روى سيستم جمهارهستهاى Intel's Core i7-950 انجام شده است. سيستمعامل مورداستفاده، لينوكس است.

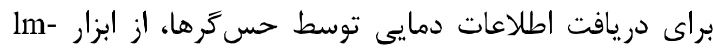

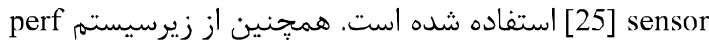
موجود در سيستمعامل لينوكس، جهت دريافت اطلاعات

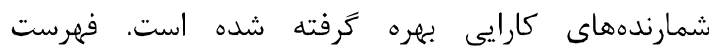
شمارندههاى كارايى در جدول (r) نمايش داده شده است.

(جدول-r): فهرست شمارندههاى كارايى

(Table-3): The list of performance counters

\begin{tabular}{|c|}
\hline نام شمارندة كارايى \\
\hline CONTEXT-SWITCHES \\
\hline CPU-MIGRATIONS \\
\hline PERF_COUNT_SW_PAGE_FAULTS \\
\hline CYCLES \\
\hline PERF COUNT HW STALLED CYCLES FRONTEND \\
\hline PERF_COUNT_HW ST SLLEED CYCLES B B $A$ CKEND \\
\hline $\begin{array}{l}\text { INSTRUCTIONS } \\
\end{array}$ \\
\hline BRANCHES \\
\hline BRANCH-MISSES \\
\hline CACHE-REFERENCES \\
\hline IO_TRANSACTIONS \\
\hline $\begin{array}{c}\text { L1D ALL REF } \\
\text { CACHE-MISSES }\end{array}$ \\
\hline
\end{tabular}

از ابزار cpufreq [26] نيز براى تنظيم يوياى ولتاز و فركانس استفاده شده است. تغيير سرعت فن با استفاده از اسكيريتيت هسته fancontrol انجام شده است. براى انجام

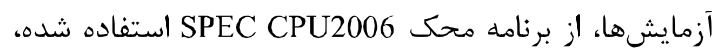
كه بلصورت موازى بر روى هستههاى يردازنده قابلاجرا

\section{ه- - تحليل آزمايش ها}

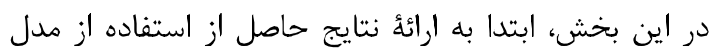

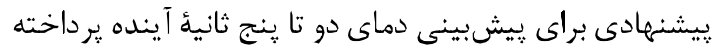

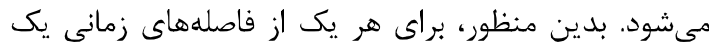

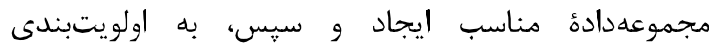

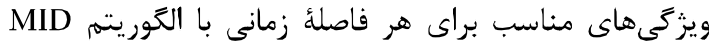

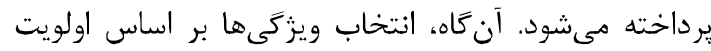

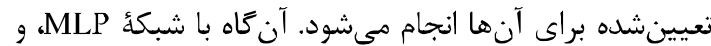

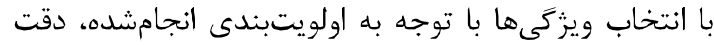

(جدول -()): جمعيت يارتوى حاصل از انتخاب ويرَّى هاى

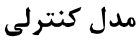

(Table-1): The pareto population derived from the features selection of control model

\begin{tabular}{|c|c|c|}
\hline خطاى تخمين & خطراى تعيين & تعداد ويزگكىها \\
\hline 0.1 & 0.22 & 1 \\
\hline 0.03 & 0.07 & 2 \\
\hline 0.01 & 0.023 & 3 \\
\hline 0.008 & 0.01 & 4 \\
\hline 0.0022 & 0.0047 & 5 \\
\hline 0.002 & 0.004 & 6 \\
\hline
\end{tabular}

با استفاده از ويزگگهاى انتخابى و مدل كنترلى

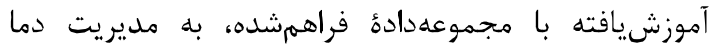

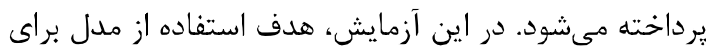

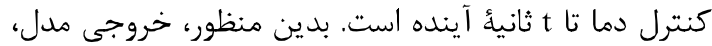

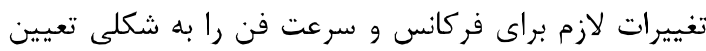

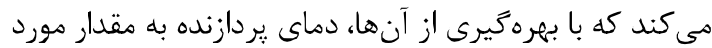

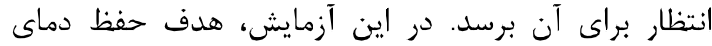

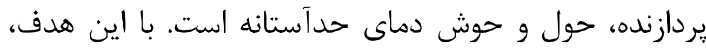
سعى مىشود كه بيشينه فركانس بردازنده و كمينه سرعت

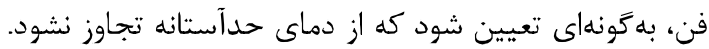

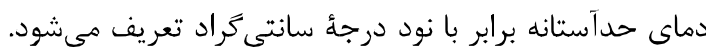

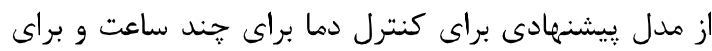
برنامههاى مختلف استفاده شده است. با توجه به اختلاف بئ بين دماى مشاهدهشده از يردازنده يس از كنترل، با باد دماى حدآستانه براى محاسبه خطاى مدل استفاده شده است. در اين راستا، مقدار MAE و SDAE براي كنترل دما براى مداى

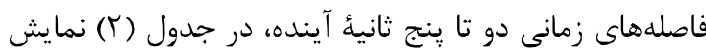

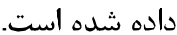
(جدول-r): دقت مدل كنترل دما براى فاصلههاى زمانى مختلف

(Table-2): The accuracy of the thermal control model for

\begin{tabular}{|c|c|c|}
\hline \multicolumn{3}{|c|}{ different time distances } \\
\hline SDAE $\left({ }^{\circ} \mathbf{C}\right)$ & $\mathbf{M} \mathbf{E}\left({ }^{\circ} \mathbf{C}\right)$ & 2 \\
\hline 0.59 & 0.49 & 3 \\
\hline 0.61 & 0.51 & 4 \\
\hline 0.68 & 0.56 & 5 \\
\hline 0.71 & 0.59 & \\
\hline
\end{tabular}

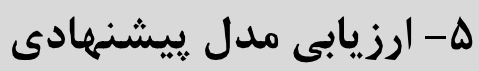

در اين بخش ابتدا سيستم קندهستهاى، ابزارها و برنامنامهاى

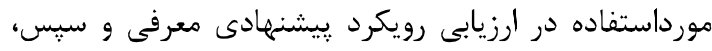


(جدول-ه): نتايج بهره

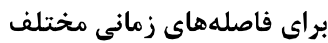

(Table-2): Results the Zhang model to predict temperature for different time distances

\begin{tabular}{|c|c|c|c|c|}
\hline $\operatorname{Pe}(\%)$ & $\begin{array}{c}\text { SDAE } \\
\left({ }^{\circ} \mathbf{C}\right)\end{array}$ & MAE $\left({ }^{\circ} \mathrm{C}\right)$ & ويزَّى هاد & زاصلة \\
\hline 0.27 & 0.68 & 0.6 & 16 & 2 \\
\hline 1.65 & 0.81 & 0.72 & 16 & 3 \\
\hline 1.85 & 0.84 & 0.8 & 16 & 4 \\
\hline 2.2 & 0.89 & 0.84 & 16 & 5 \\
\hline
\end{tabular}

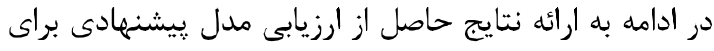

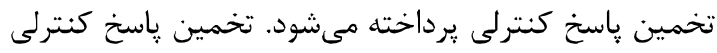

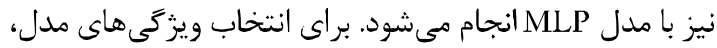

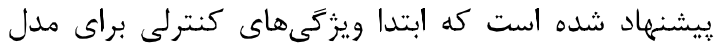

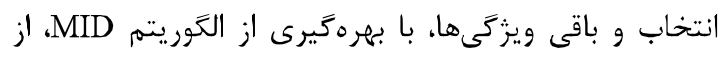
ميان ويزگكىهاى سابقهاى انتخاب مى شوند. نتيجة استفاده از

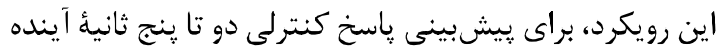

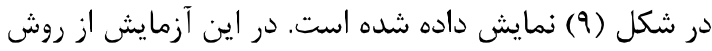
اعتبارسنجى K تايى استفاده شده است.

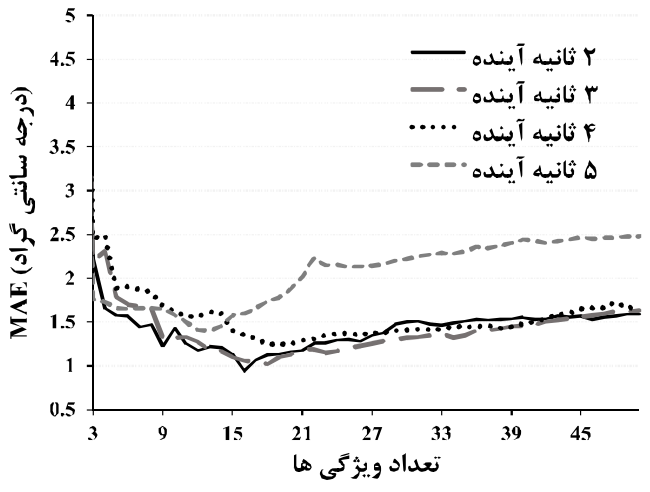

(شكل -9): دقت مدل يُشبينى ياسخ كنترلى براى

فاصلههاى زمانى مختلف

(Figure-9): The accuracy of the control responce prediction model for different time distances

براى ارزيابى دقيقتر رويكرد يِينهادى در ايجاد مدل

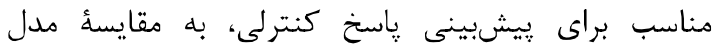

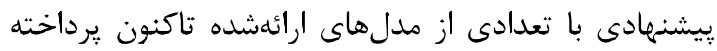

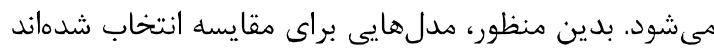
كه نتايج خوبى را در اين راستا ارائه كردهاند. در ابتدا، نتايج

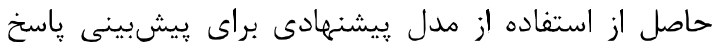

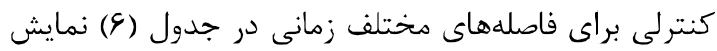

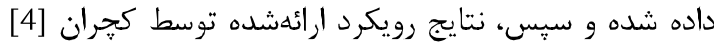

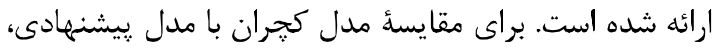

بيشبينى دما محاسبه مىشود. نتايج بهدستآمده در شكل

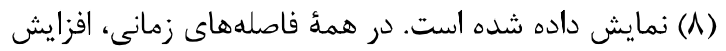

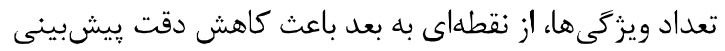

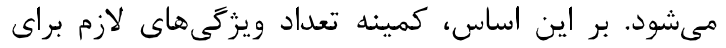

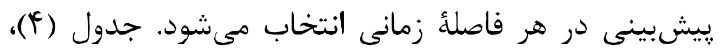

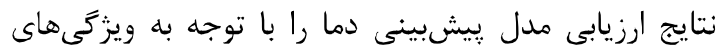
انتخابى براى هر فاصلهُ زمانى نشان مى دهدئ.

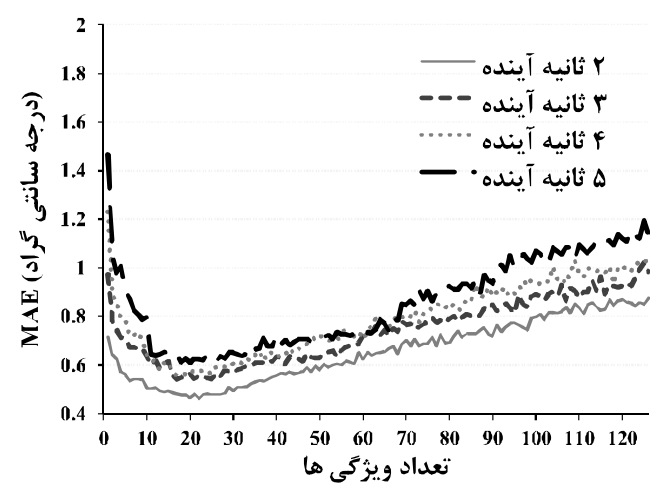

(شكل-1): دقت مدل يِيشبينى دما براى فاصله هاى

$$
\text { مختلف زمانى }
$$

(Figure-8): The accuracy of the thermal prediction model for different time distances

(جدول - F) : ارزيابى معيارهاى دقت يِيشبينى دما براى

فاصله هاى زمانى مختلف

(Table-4|): Evaluation of temperature prediction

accuracy criteria for different time distances

\begin{tabular}{|c|c|c|c|c|}
\hline $\operatorname{Pe}(\%)$ & $\begin{array}{c}\text { SDAE } \\
\left({ }^{\circ} \mathbf{C}\right)\end{array}$ & $\begin{array}{c}\text { MAE } \\
\left({ }^{\circ} \mathbf{C}\right)\end{array}$ & ويزتى هداد & زماصلة \\
\hline 0.04 & 0.59 & 0.47 & 17 & 2 \\
\hline 0.14 & 0.64 & 0.55 & 16 & 3 \\
\hline 0.14 & 0.67 & 0.55 & 17 & 4 \\
\hline 0.2 & 0.69 & 0.61 & 12 & 5 \\
\hline
\end{tabular}

دقت بالا در همأ معيارهاى ارزيابى، نشان از ويزّكىهاى

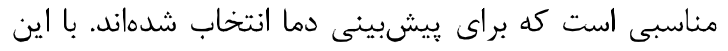

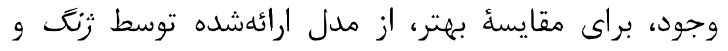

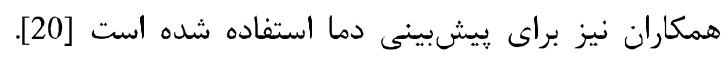

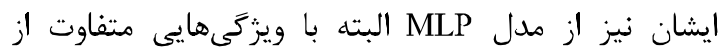
ويثزى هاى انتخابشده براى مدل پِيشنهادى در اين مقاله،

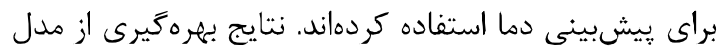

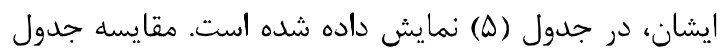

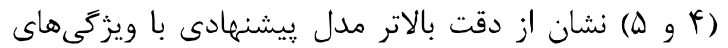
انتخابشده براى آن دارد. 
مدل بيشبينى ياسخ كنترلى، براى يكى هسته در

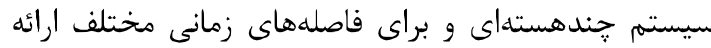

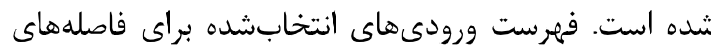

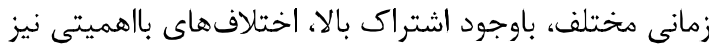

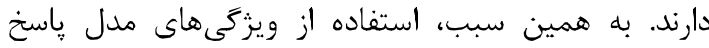
كنترلى براى يكفاصله زمانى، نتيجه مناسبى براى يك فئ فاصله

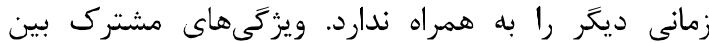

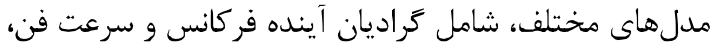

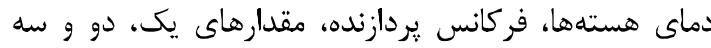

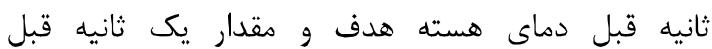

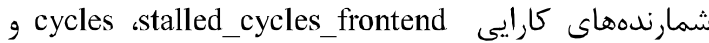

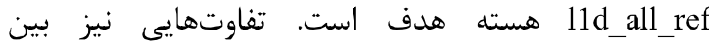

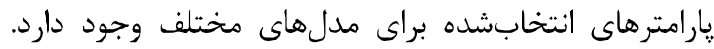

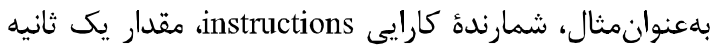

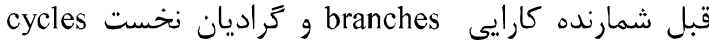
براى تخمين ياسخ كنترلى دو و سه ثانيه آينده انتخاب شده

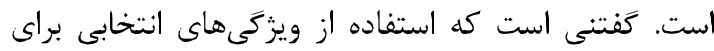

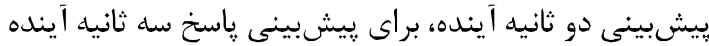

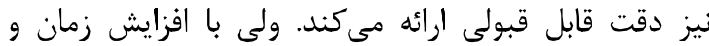

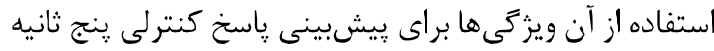

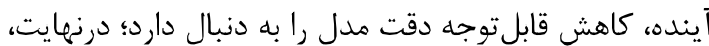

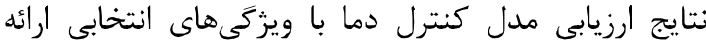

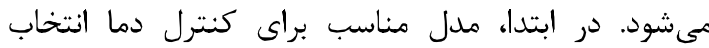

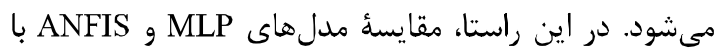

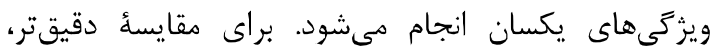

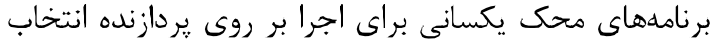

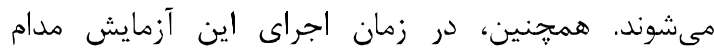

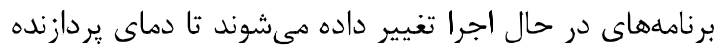

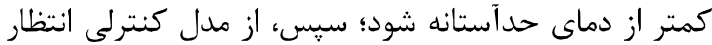

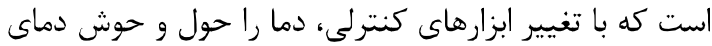

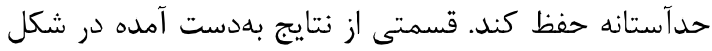

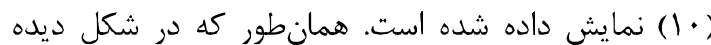

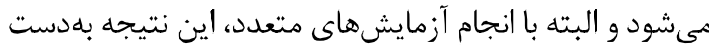

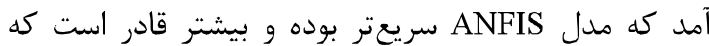

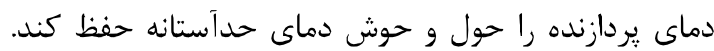

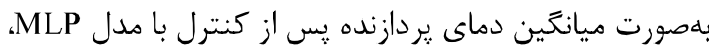

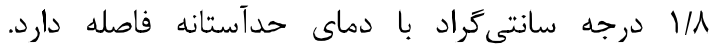

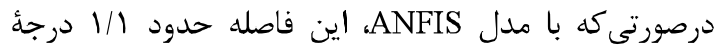

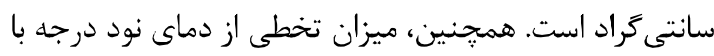

بيادهسازى اين رويكرد براى فاصلههاى مختلف زمانى و بر بر بران

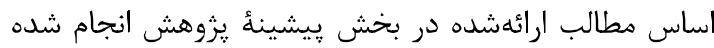

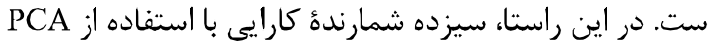

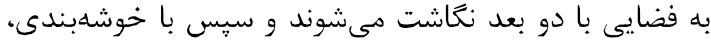

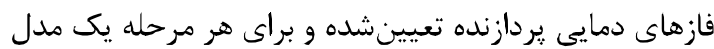

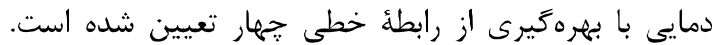

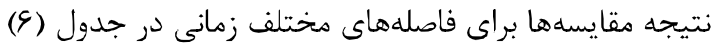

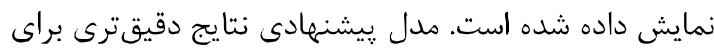

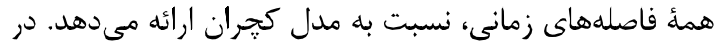

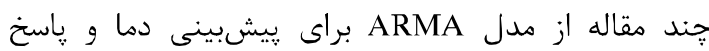

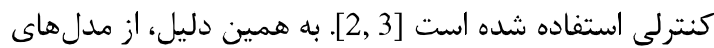

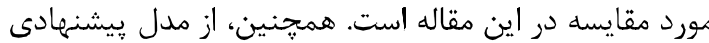

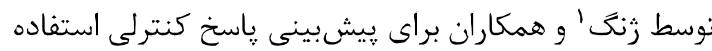

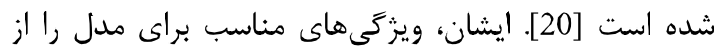
ميان ويزُكى هاى فيزيكى و برنامهاى، با استفاده از الكوريتم

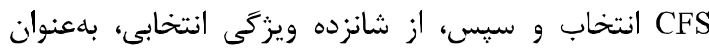

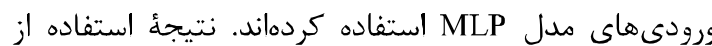

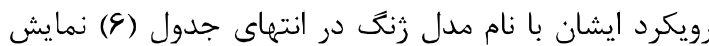
داده شده است.

(جدول-8): ارزيابى تعدادى از مدلهاى ييشبينى هاسخ

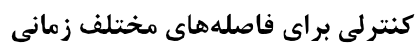

(Table-6): The evaluations of some control response prediction models for different time distances

\begin{tabular}{|c|c|c|c|c|}
\hline $\begin{array}{c}\mathrm{Pe} \\
(\%)\end{array}$ & $\begin{array}{l}\text { SDAE } \\
\left({ }^{\circ} \mathbf{C}\right)\end{array}$ & $\begin{array}{c}\text { MAE } \\
\left({ }^{\circ} \mathbf{C}\right)\end{array}$ & زاصله & مدل \\
\hline 3 & 1.02 & 0.94 & 2 & ييشنه|دى \\
\hline 3.2 & 1.1 & 1.02 & 3 & ييشنهادى \\
\hline 4.1 & 1.28 & 1.24 & 4 & ييشنهادى \\
\hline 5.2 & 1.42 & 1.4 & 5 & ييشنهادى \\
\hline 8 & 2.2 & 1.4 & 2 & كجران \\
\hline 11 & 2.5 & 1.7 & 3 & كجران \\
\hline 15 & 2.8 & 2.1 & 4 & كجران \\
\hline 20 & 3 & 2.6 & 5 & كجران \\
\hline 11 & 2.83 & 1.63 & 2 & ARMA \\
\hline 11 & 2.94 & 1.74 & 3 & ARMA \\
\hline 16 & 3.46 & 2.09 & 4 & ARMA \\
\hline 17 & 3.67 & 2.49 & 5 & ARMA \\
\hline 8.4 & 2.27 & 1.37 & 2 & زنگ \\
\hline 9.6 & 2.48 & 1.61 & 3 & زنز \\
\hline 11.4 & 2.86 & 1.9 & 4 & زنَ \\
\hline 14.3 & 2.92 & 2.21 & 5 & زنگت \\
\hline
\end{tabular}

Zhange 


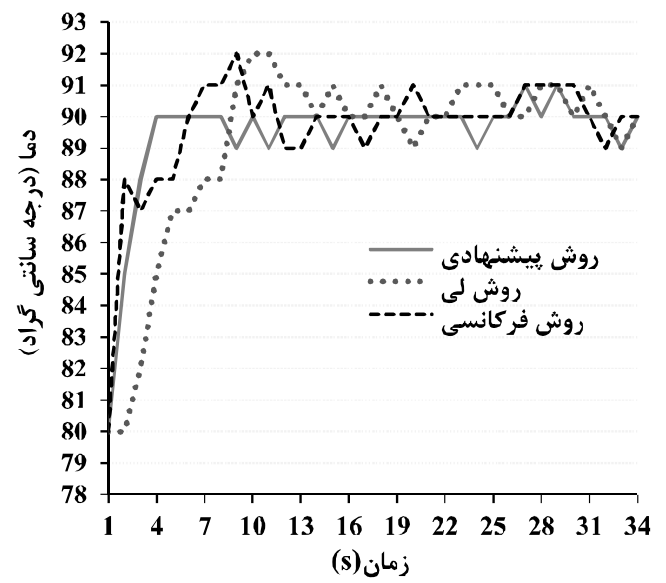

(شكل -1|): مقايسه سه روش كنترل دما با هدف حفظ دما حول و حوش دماى حدآستانه

(Figure-11): Comparison of three thermal control methods to maintain temperature around the threshold temperature

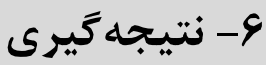

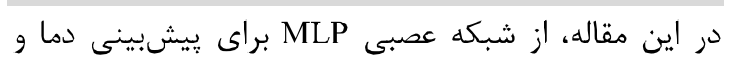

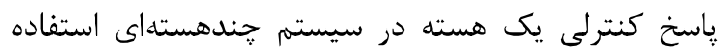

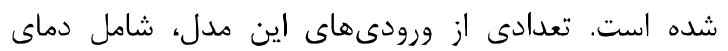

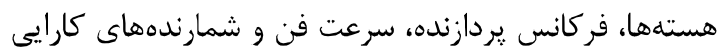

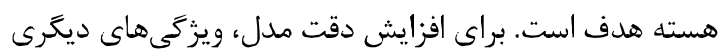

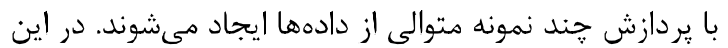

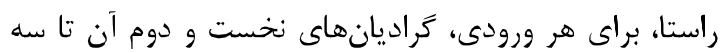

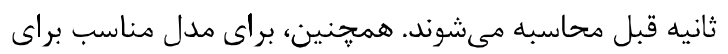

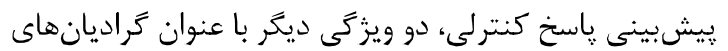

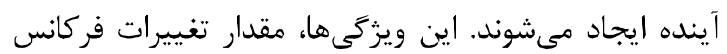

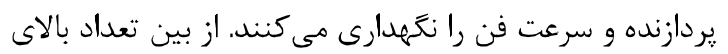

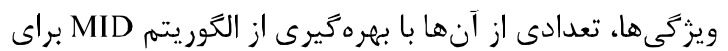

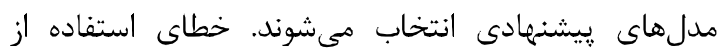

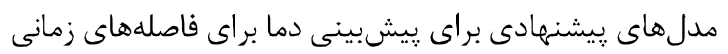

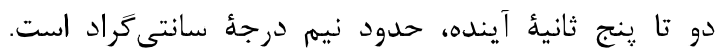

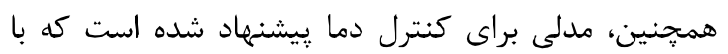

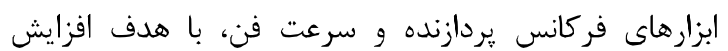

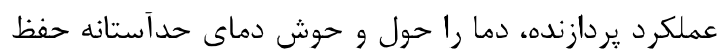

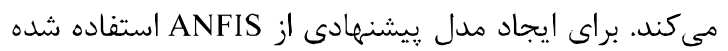

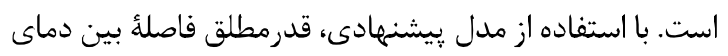

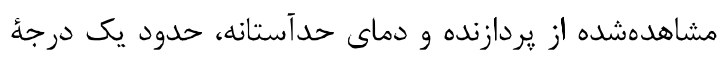
سانتى كراد بهدست آمده است.
مدلهاى MLP و ANFIS، بهتر تيب حدود هشت و دو درصد

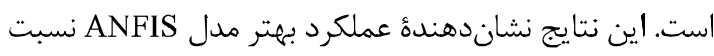

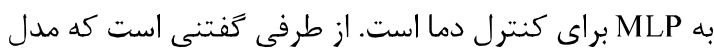

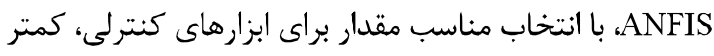

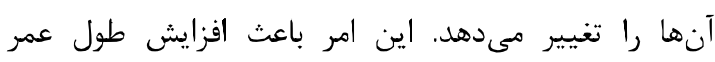
ابزار هايى مانند فن يردازنده ميى دهود.

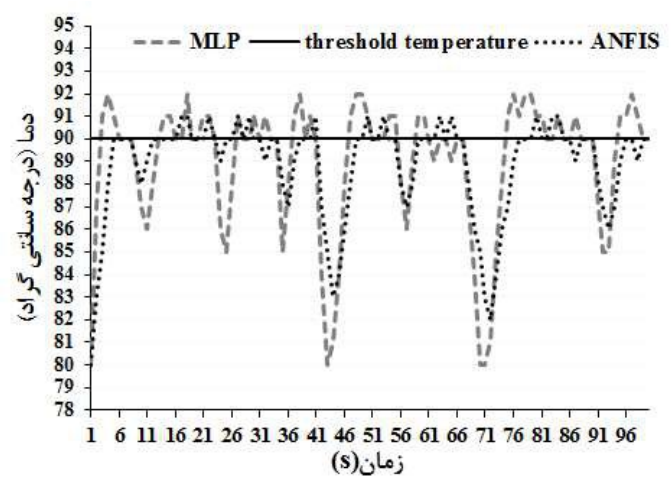

(شكل -+1): كنتر ل دماى يردازنده با استفاده از مدلهاى MLP, ANFIS

(Figure-10): processor thermal control using ANFIS and MLP models

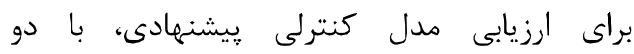

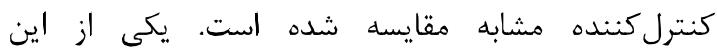

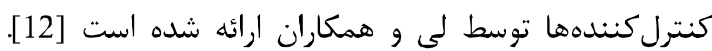
ايشان ابتدا از تغييرات سرعت فن در جهت تغيير دما به سمت

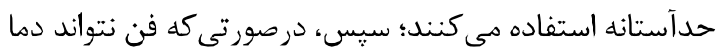
را حول و حوش حدآستانه حفظ كند، از تغييرات فركانس بهره دئن

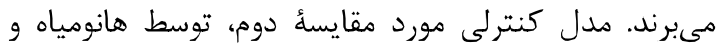

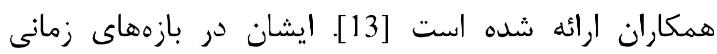

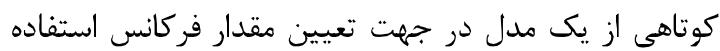

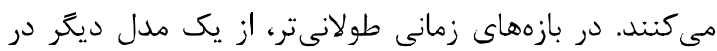
جهت تعيين مقدار براى سرعت فن استفاده مىكنند.

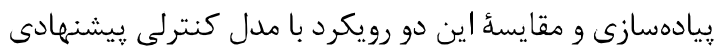

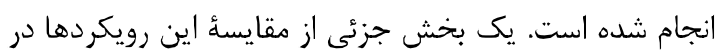

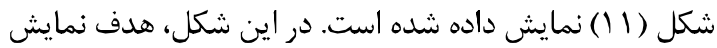

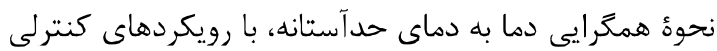

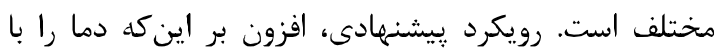
سرعت بالايى به دماى حدآستانه همحرا مى كند، از تغييرات آنسات

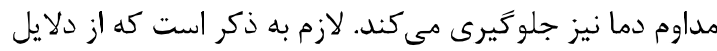

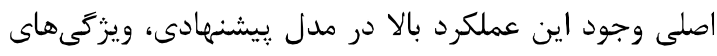

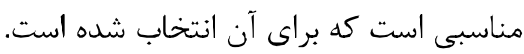


[12] D. Li, R. Ge, and K. Cameron, "System-level, Unified In-band and Out-of-band Dynamic Thermal Control, " In International Conference Parallel Processing (ICPP), 2010, pp. 131-140.

[13] V. Hanumaiah and S. Vrudhula, "Energyefficient operation of multicore processors by DVFS, task migration, and active cooling, " IEEE Transactions on Computers, vol .63, no. 2, pp. 349-360, 2014

I. Yeo, C.C. Liu, and E.J. Kim, "Predictive dynamic thermal management for multicore systems," Proc. 45th annual Design Automation Conference, 2008, pp. 734-739.

[14] G. Liu, M. Fan, and G. Quan, "Neighbor-aware dynamic thermal management for multi-core platform," Proc. Design, Automation \& Test in Europe Conference \& Exhibition (DATE), 2012 pp. 187-192.

[15] A. Kumar, L. Shang, L.S. Pch, and N. K. Jha, "HybDTM: a coordinated hardware-software approach for dynamic thermal management," Proc. Design Automation Conference, 2006, pp. 548-553.

[16] K.J. Lee and K. Skadron, "Using performance counters for runtime temperature sensing in high-performance processors," IEEE International Parallel and Distributed Processing Symposium, 2005.

[17] S. J. Lu, R. Tessier, and W. Burleson, "Dynamic On-Chip Thermal Sensor Calibration Using Performance Counters," IEEE Trans. on Computer-Aided Design of Integrated Circuits and Systems, vol. 33, no. 6, pp. 853-866, 2014.

[18] K. Skadron, M. R. Stan, W. Huang, S. Velusamy, K. Sankaran-Arayanan, and D. Tarjan, "Temperature aware microarchitecture: Extended discussion and results," Technical Report CS-2003-08, University of Virginia, Dept. of Computer Science, 2003.

[19] K. Zhang, A. Guliani, S. Ogrenci-Memik, G. Memik, K. Yoshii, R. Sankaran, and P. Beckman, "Machine Learning-Based Temperature Prediction for Runtime Thermal Management Across System Components, " IEEE Trans. on Parallel and Distributed Systems, vol. 29, no. 2, pp. 405-419, 2018.

[20] J. M. N. Abad, B. Salami, H. Noori, A. Soleimani and F. Mehdipour, "A neuro-fuzzy fan speed controller for dynamic thermal management of multi-core processors," In Proceedings of the 11th ACM Conference on Computing Frontiers, 2014, p. 29.

[21] J. M. N. Abad and A. Soleimani, "A neuro-fuzzy fan speed controller for dynamic management of processor fan power consumption," In Swarm Intelligence and Evolutionary Computation (CSIEC), pp. 148-153, 2016.

\section{7- References}

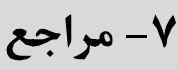

[1] J. Kong, S. W. Chung, and K. Skadron, "Recent thermal management techniques for microprocessors," ACM Computing Surveys (CSUR), vol. 44, p. 13, 2012.

[2] A. K. Coskun, T. S. Rosing, and K. C. Gross, "Utilizing predictors for efficient thermal management in multiprocessor SoCs," IEEE Trans. on Computer-Aided Design of Integrated Circuits and Systems, vol. 28, no. 10, pp. 15031516, 2009.

[3] A. K. Coskun, T. S. Rosing, and K. C. Gross, "Proactive temperature balancing for low cost thermal management in MPSoCs," Proc. IEEE/ACM International Conference on Computer-Aided Design, 2008, pp. 250-257.

[4] R. Cochran and S. Reda, "Thermal prediction and adaptive control through workload phase detection," ACM Trans. on Design Automation of Electronic Systems (TODAES), vol. 18, no. 1, p. 7, 2013.

[5] M. Chhablani, I. Koren, and C. M. Krishna, "Online Inertia-Based Temperature Estimation for Reliability Enhancement," Journal of Low Power Electronics, vol. 12, no. 3, pp. 159-171, 2016.

[6] M. Zaman, A. Ahmadi, and Y. Makris, "Workload characterization and prediction: A pathway to reliable multi-core systems," Proc. International On-Line Testing Symposium (IOLTS), pp. 116-121, 2015.

[7] M. Stockman, M. Awad, H. Akkary, and R. Khanna, "Thermal status and workload predicttion using support vector regression," Proc. International Conference on Energy Aware Computing, 2012, pp. 1-5.

[8] Y. Ge, Q. Qiu, and Q. Wu, "A multi-agent framework for thermal aware task migration in many-core systems," IEEE Trans. on Very Large Scale Integration (VLSI) Systems, vol. 20, no. 10 , pp. 1758-1771, 2012.

[9] P. Kumar and D. Atienza, "Neural network based on-chip thermal simulator," Proc. Circuits and Systems (ISCAS), pp. 1599-1602, 2010.

[10] A. Vincenzi, A. Sridhar, M. Ruggiero, and D. Atienza, "Fast thermal simulation of $2 \mathrm{D} / 3 \mathrm{D}$ integrated circuits exploiting neural networks and GPUs," Proc. 17th IEEE/ACM international symposium on low-power electronics and design, pp. 151-156, 2011.

[11] A. Sridhar, A. Vincenzi, M. Ruggiero, and D. Atienza, "Neural network-based thermal simulation of integrated circuits on GPUs," IEEE Trans. on Computer-Aided Design of Integrated Circuits and Systems, vol. 31, no. 1, pp. 23-35, 2012. 


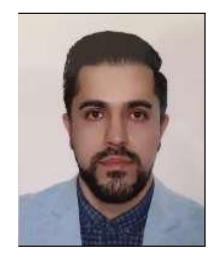

باقر سلامى مدرى كارشناسى خود را در رشته مهندسى كامييوتر از دانشكاه

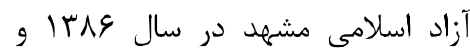

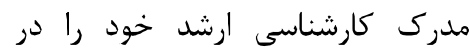
همين رشته از دانشخاه فردوسى مشهد آندادئ

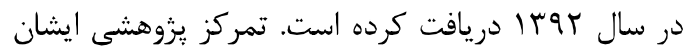
در زمينه مديريت توان مصرفى و دماى يردازندهها است.

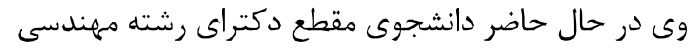

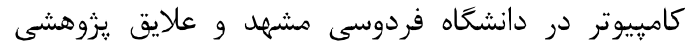

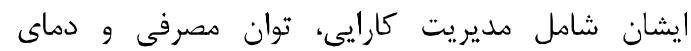
يردازندهاى קندهستهاى، طراحى سيستمهاى نهفتئه، سيستمهاى جند يردازندهاى روى يك تراشه و برنامهنويسى سئى موازى است.

bagher.salami@stu-mail.um.ac.ir
[22] H. Peng, F. Long, and C. Ding, "Feature selection based on mutual information criteria of max-dependency, max-relevance, and minredundancy," IEEE Trans. on pattern analysis and machine intelligence, vol. 27, no. 8, pp. 1226-1238, 2005.

[23] C. Ding and H. Peng, "Minimum redundancy feature selection from microarray gene expression data," Journal of bioinformatics and computational biology, vol. 3, no. 2, pp. 185205, 2005.

[24] 1m-sensors Linux hardware monitoring [Online]. Available: http://www.lm-sensors.org, Jan 2017.

[25] Linux cpufreq governors, LinuxKernel [Online]. Available:https://www.kernel.org/doc/Documen tation/cpu-freq/governors.txt. Jan 2017.

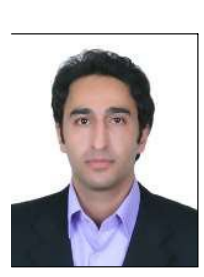

جواد محبى نجم آباد مقطع كارشناسى و كارشناسى ارشد را در زرايش مهندسى نرمافزار كَرانده است. همجنين، مقطع دكترا را در رشته كامبيوتر-كرايش هوش

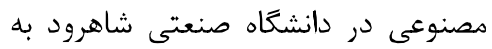
اتمام رسانده است. ايشان عضو هيأت علمى دانشخاه آزاد داد دان

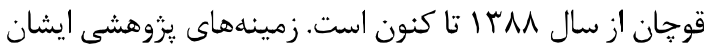

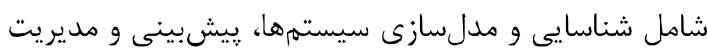
دما و توان مصرفى در سيستمهاى ختندهستهاى است.

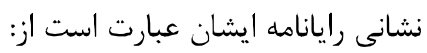
javad.mohebi@gmail.com

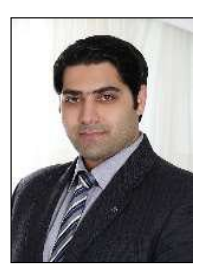

مرتضى مرادى مدرك كارشناسى و و

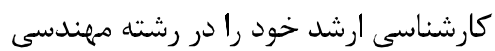

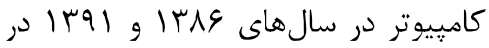
كرايش مهندسى نرمافزار كسب كرده است. در حال حاضر، ايشان در حال كسب مدرك دكتراى مرهندسى كامييوتر از گروه كامِييوتر در دانشعَاه

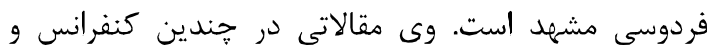

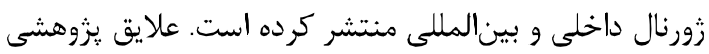
او شامل محاسبات موازى، مديريت دما و انرزى يردازنده، دئي

$$
\text { زيست محاسباتى و التوريتمها است. }
$$

moradi.edu@gmail.com 